\title{
A Decade of System Justification Theory: Accumulated Evidence of Conscious and Unconscious Bolstering of the Status Quo
}

\author{
John T. Jost \\ Department of Psychology, New York University
}

\author{
Mahzarin R. Banaji \\ Department of Psychology and Radcliffe Institute for Advanced Study, \\ Harvard University
}

Brian A. Nosek

Department of Psychology, University of Virginia

\begin{abstract}
Most theories in social and political psychology stress self-interest, intergroup conflict, ethnocentrism, homophily, ingroup bias, outgroup antipathy, dominance, and resistance. System justification theory is influenced by these perspectives-including social identity and social dominance theories-but it departs from them in several respects. Advocates of system justification theory argue that (a) there is a general ideological motive to justify the existing social order, (b) this motive is at least partially responsible for the internalization of inferiority among members of disadvantaged groups, $(c)$ it is observed most readily at an implicit, nonconscious level of awareness and (d) paradoxically, it is sometimes strongest among those who are most harmed by the status quo. This article reviews and integrates 10 years of research on 20 hypotheses derived from a system justification perspective, focusing on the phenomenon of implicit outgroup favoritism among members of disadvantaged groups (including African Americans, the elderly, and gays/lesbians) and its relation to political ideology (especially liberalism-conservatism).
\end{abstract}

KEY WORDS: ideology, system justification, intergroup relations, implicit bias

There is a cluster of related theories that are by now so prevalent in social science that they strike the contemporary reader as self-evidently true. Although these theories are by no means indistinguishable, they share a set of common features, including the tenets that groups serve their own interests, develop ideolo- 
gies to justify those interests, have strong preferences for members of their own kind, are hostile and prejudicial toward outsiders, and are conflict-seeking whenever it helps to advance their partisan interests and particularistic identities. For the sake of classification — and in order to contrast them with our own approachwe refer to these as "group justification" theories (see also Jost \& Banaji, 1994). They hold that people are driven by ethnocentric motives to build ingroup solidarity and to defend and justify the interests and identities of fellow ingroup members against those of outgroup members. Such theories may contain one or more of the following specific assumptions:

Similar others are preferred to dissimilar others. (Allen \& Wilder, 1975; Brewer, 1979; Tsui, Egan, \& O’Reilly, 1992)

Prejudice is a form of hostility directed at outgroup members. (Adorno, Frenkel-Brunswik, Levinson, \& Sanford, 1950; Allport, 1954; Brown, 2000b; Pettigrew, 1982)

Intergroup relations in society are inherently competitive and conflictridden. (Bobo, 1988; Sherif, 1967; Sidanius \& Pratto, 1999)

Intergroup behavior is driven primarily by ethnocentrism and ingroup favoritism. (Brewer \& Campbell, 1976; Brewer \& Miller, 1996; Sumner, 1906; Tajfel \& Turner, 1986)

Prejudice, discrimination, and institutionalized oppression are inevitable outcomes of intergroup relations. (Sidanius \& Pratto, 1993)

Members of dominant groups strive to impose their hegemonic will on members of subordinated groups. (Fiske, 1993; Sidanius \& Pratto, 1999)

Members of subordinated groups first seek to escape the implications of group membership by exercising individual exit and mobility options. (Ellemers, Wilke, \& van Knippenberg, 1993; Hirschman, 1970; Tajfel, 1975)

When individual exit/mobility is impossible, members of subordinated groups engage in identity enhancement strategies of resistance and competition. (Scott, 1990; Spears, Jetten, \& Doosje, 2001; Tajfel \& Turner, 1986)

In coping with chronically threatened social identities, members of subordinated groups typically express stronger levels of ingroup favoritism than do members of dominant groups. (Leach, Spears, Branscombe, \& Doosje, 2003; Mullen, Brown, \& Smith, 1992)

Political ideology mirrors/group membership individual and collective self-interest and/or social position. (Centers, 1949; Downs, 1957; Olson, 1971; Sidanius, Singh, Hetts, \& Federico, 2000) 
A sense of injustice is triggered by violations of relative standards or established fairness norms. (Deutsch, 1985; Gurr, 1970; Taylor \& Moghaddam, 1994; Walker \& Smith, 2002)

In the social scientific imagination, it is as if the advantaged are relentlessly looking to cash in on their dominance and the disadvantaged are proud revolutionaries-in-waiting. Both types of groups are seen as primarily self-interested, and overt conflicts of interest are assumed to be endemic. ${ }^{1}$

In this paper, we question these common, almost ubiquitous assumptions and make a case for a contrary perspective. We challenge these conventionally accepted principles not because we think that they are unhelpful or incorrect or fail to capture the modal case, but because the many notable exceptions and deviations are instructive, revealing, and helpful for creative theory-building (see McGuire, 1997). The received view is a good story, but it is not the whole story. We think that it needs to be supplemented with an alternative theoretical perspective that takes the important exceptions seriously. In this article, we further advance a psychological theory of system justification, defined as the "process by which existing social arrangements are legitimized, even at the expense of personal and group interest" (Jost \& Banaji, 1994, p. 2). Specifically, we review 10 years of research stimulated by a system justification perspective on intergroup relations, and we present some new data pertaining to the ideological basis of conscious and nonconscious intergroup attitudes.

\section{The Accumulation of Evidence Against the Received View}

In recent years, evidence against the propositions listed above has been accumulating, and a number of commentators have begun to express dissatisfaction with pieces of the received view. Jackman (1994), for instance, railed against "conflict theories" of intergroup relations and the conception of prejudice as "irrational antagonism." She suggested that, from a system maintenance perspective, there is far more to be gained by members of dominant groups fostering cooperative, even affectionate relationships with their subordinates. Her historical and survey research shows that dominants and subordinates are highly averse to conflict and antagonism and generally develop collaborative relationships, even within the context of dramatically inegalitarian institutions such as slavery. Glick and Fiske (2001) similarly criticized Allport's (1954) popular definition of prejudice as antipathy for failing to explain benevolent forms of sexism. They showed that seemingly favorable attitudes toward women can help to sustain gender

\footnotetext{
${ }^{1}$ The assumption of universal self-interest, whether made by social scientists or lay people, may itself contribute to system justification, insofar as it justifies self-interested behavior on the part of advantaged group members by suggesting that everyone-including members of disadvantaged groupsequivalently embraces self-interest (which is not the case, as we will show).
} 
inequality and discriminatory systems and should therefore be considered prejudicial, even though such attitudes are highly appealing to many women (e.g., Kilianski \& Rudman, 1998). The weight of evidence is also mounting against the notion that ingroup bias is a default feature of intergroup relations and that members of low-status groups typically use a wide repertoire of identity enhancement strategies. To take one example from the survey literature, Sniderman and Piazza (1993) found in a large, nationally representative sample that African American respondents generally accepted unfavorable stereotypes of their own group as lazy, irresponsible, and violent. Indeed, they endorsed these stereotypes even more strongly than European American respondents did. Experimental and field studies have since shown that members of disadvantaged groups often hold ambivalent, conflicted attitudes about their own group membership and surprisingly favorable attitudes toward members of more advantaged groups (e.g., Jost \& Burgess, 2000; Jost, Pelham, \& Carvallo, 2002). On the basis of these and other findings, Smith and Mackie (2002) concluded that intergroup attitudes are more complex and differentiated than the received view allows. Ingroup favoritism and outgroup derogation may be relatively common, but they are by no means the only reactions that people have to social groups, especially when status and power differences are involved.

Miller (1999) argued persuasively that self-interest is a product of social and cultural norms rather than a universal "fact" about human motivation. Empirical studies conducted by Miller and Ratner (1998) demonstrate that group memberships have much weaker effects on social attitudes than observers assume. With regard to political attitudes, there is notoriously little correspondence between indicators of self-interest (such as income, social class, and demographic group membership) and ideology (e.g., Jost, Glaser, Kruglanski, \& Sulloway, 2003a; Lane, 1959/2004; Lipset, 1981; Sears \& Funk, 1991; Sidanius \& Ekehammar, 1979; Stacey \& Green, 1971; Wilson, 1973). Even on issues that should be highly relevant to considerations of self-interest, such as policies of economic distribution, research repeatedly shows that low-income groups are scarcely more likely than high-income groups to support such policies, although they would obviously benefit from them (Fong, 2001; Gilens, 1999; Jost, Pelham, Sheldon, \& Sullivan, 2003; Kluegel \& Smith, 1986). In a similar vein, Newman (2002) concluded on the basis of her urban ethnographic work that, in defiance of current sociological theories, "ghetto dwellers are neither the passive victims of nor the heroic resisters against capitalist or racist exploitation" (p. 1586). Evidence against the received view has been accumulating, and much of it is more consistent with a system justification perspective that stresses accommodation and rationalization of the status quo than with identity-based or interest-based theories.

Like all contemporary researchers of intergroup relations, we have been influenced immensely by theories of social identification (Tajfel \& Turner, 1986) and social dominance (Sidanius \& Pratto, 1999). From our viewpoint, however, these approaches are hampered by adhering so closely to conventional assumptions of 
self-interest, homophily, ingroup bias, outgroup antipathy, and intergroup conflict. In the case of social identity theory, Tajfel (1975) absorbed much of this framework from Hirschman's (1970) rational choice analysis of exit versus loyalty. Other aspects may have resulted from Tajfel and Turner's (1986) overgeneralization of results from the minimal group paradigm in an effort to explain very different contexts involving longstanding inequalities between groups. With regard to social dominance theory, assumptions of self-interest may derive from a reading of evolutionary theory in which, among other things, ethnocentrism among humans is seen as determined by inclusive fitness as an extension of "genetic selfishness" (Sidanius \& Pratto, 1999, p. 27).

To the limited extent that these theories address attitudes toward the overarching social system (rather than intergroup attitudes), they tend to regard the social order as something that is imposed by one group and resisted by the other. ${ }^{2}$ This is their strength - because there is considerable heuristic value in making such an assumption - but it is also their weakness. The image of intergroup relations that results is overly self-interested and insufficiently ideological; these two criticisms are not contradictory, because ideology is motivated by many factors in addition to self-interest (Jost et al., 2003a). Theories of social identity and social dominance fail to account for the degree to which psychological responses to the social and political status quo are characterized by active bolstering and system justification, especially among members of disadvantaged groups. That is, hierarchy is maintained not only through mechanisms of ingroup favoritism and outgroup derogation exercised by members of dominant groups, but also by the complicity of members of subordinated groups, many of whom perpetuate inequality through mechanisms such as outgroup favoritism.

To illustrate the one-sided emphasis on homophily, ingroup favoritism, and ethnocentrism (and the corresponding neglect of outgroup favoritism), we have listed in Table 1 several books on social identity and intergroup relations, comparing the number of index entries for "ingroup bias" and "ingroup favo(u)ritism" to entries for "outgroup bias" and "outgroup favo(u)ritism." For 11 books published between 1981 and 2000, there were 142 index entries for ingroup favoritism, whereas there were 12 entries for outgroup favoritism, 8 of which came from a single chapter by Hinkle and Brown (1990). This one-sidedness is not accidental. Prevailing theories contain a much more developed set of explanatory concepts around the struggle to foster positive group distinctiveness and to favor ingroup members than around the motive to justify the status quo and the tendency to internalize status hierarchies. Framing theories around concepts of

\footnotetext{
${ }^{2}$ On this issue, Havel (1991) wrote perceptively that "only a very generalized view (and even that only approximative) permits us to divide society into the rulers and the ruled.... In the posttotalitarian system [the line of conflict] runs de facto through each person, for everyone in his own way is both a victim and a supporter of the system. What we understand by the system is not, therefore, a social order imposed by one group upon another, but rather something which permeates an entire society and is a factor in shaping it" (p. 144).
} 
Table 1. Number of Subject Index Entries in Books on Social Identification and Intergroup Relations Referring to Ingroup Favoritism and Outgroup Favoritism, 1981-2000

\begin{tabular}{lcc}
\multicolumn{1}{c}{ Book } & $\begin{array}{c}\text { Ingroup } \\
\text { favoritism/ } \\
\text { ingroup bias }\end{array}$ & $\begin{array}{c}\text { Outgroup } \\
\text { favoritism/ } \\
\text { outgroup bias }\end{array}$ \\
\hline Turner \& Giles (1981) & 21 & 0 \\
Tajfel (1984, both volumes) & 6 & 0 \\
Turner, Hogg, Oakes, Reicher, \& Wetherell (1987) & 8 & 0 \\
Brown (1988) & 24 & 0 \\
Abrams \& Hogg (1990) & 13 & $8^{\mathrm{a}}$ \\
Oakes, Haslam, \& Turner (1994) & 7 & 1 \\
Taylor \& Moghaddam (1994) & 5 & 0 \\
Stephan \& Stephan (1996) & 3 & 0 \\
Spears, Oakes, Ellemers, \& Haslam (1997) & 38 & $3^{\mathrm{b}}$ \\
Sedikides, Schopler, \& Insko (1998) & 6 & 0 \\
Brown (2000b) & 11 & 0 \\
Total & 142 & 12 \\
Average per book & 12.9 & 1.1 \\
\hline
\end{tabular}

${ }^{a}$ All eight of these entries refer to a chapter by Hinkle and Brown (1990).

${ }^{b}$ Two of these three entries refer to a chapter by Stangor and Jost (1997).

"identification" and "dominance" dictates a focus on difference, conflict, and the advancement of specific group interests.

The neglect of system-justifying processes is ironic, given that the historical record reveals far more acquiescence than identity-based competition or revolt on the part of disadvantaged group members. Zinn (1968), for example, noted that

Society's tendency is to maintain what has been. Rebellion is only an occasional reaction to suffering in human history; we have infinitely more instances of forbearance to exploitation, and submission to authority, than we have examples of revolt. Measure the number of peasant insurrections against the centuries of serfdom in Europe-the millennia of landlordism in the East; match the number of slave revolts in America with the record of those millions who went through their lifetimes of toil without outward protest. What we should be most concerned about is not some natural tendency towards violent uprising, but rather the inclination of people, faced with an overwhelming environment, to submit to it. (pp. 16-17)

In the remainder of this article, we demonstrate that a theory of system justification like the one we proposed a decade ago (Jost \& Banaji, 1994) is needed to account for the full range of empirical evidence pertaining to the causes, consequences, and depth of the individual's psychological investment in the existing 
social system, especially when that investment contradicts his or her own selfinterest and/or ingroup solidarity.

We argue that there is a general (but not insurmountable) system justification motive to defend and justify the status quo and to bolster the legitimacy of the existing social order. Such a motive is not unique to members of dominant groups. We see it as comparable-in terms of its strength and social significance-to widely documented motives to defend and justify the interests and esteem of the self-concept and the social group (Brewer, 1979; Cialdini et al., 1976; Greenwald, 1980; Tajfel \& Turner, 1986). We expand previous theoretical notions and claim that people want to hold favorable attitudes about themselves and about their own groups, but they also want to hold favorable attitudes about social and political systems that affect them.

\section{Ego, Group, and System Justification Motives}

Jost and Banaji (1994) distinguished among three different justification tendencies or motives that have the potential to be in conflict or contradiction with one another for members of disadvantaged groups. The first motive is "ego justification," and it describes the need to develop and maintain a favorable selfimage and to feel valid, justified, and legitimate as an individual actor. The second is referred to as "group justification," and this is the primary focus of social identity theory, namely the desire to develop and maintain favorable images of one's own group and to defend and justify the actions of fellow ingroup members. The third is "system justification," and it captures social and psychological needs to imbue the status quo with legitimacy and to see it as good, fair, natural, desirable, and even inevitable. Within this theoretical framework, one can see that members of disadvantaged groups are likely to engage in social change only when ego justification and/or group justification motives overcome the strength of system justification needs and tendencies.

Because system justification theory distinguishes more clearly than other theories among the three motives of ego, group, and system justification, it has taken the lead, even over its predecessors, in identifying the social and psychological consequences of supporting the status quo, especially among members of lowstatus groups (see also Jost, Burgess, \& Mosso, 2001). Because social identity theory locates all social behavior on a continuum ranging from "interpersonal" to “intergroup" behavior (e.g., Tajfel, 1981; Tajfel \& Turner, 1986), it has contributed much to our understanding of the first two motives (ego and group justification) and the relations between them, but it has done relatively little to advance our understanding of system justification processes. Tajfel and Turner (1986) hinted that people may find it difficult to imagine "cognitive alternatives," but they did not explain the origins of this difficulty, nor does such an assumption follow from other tenets of social identity theory. 
Social dominance theory has addressed the second and third motives (group and system justification), but in such a way that they are frequently conflated with one another. Jost and Thompson (2000) demonstrated that some items from the Social Dominance Orientation (SDO) scale load onto a "group-based dominance" factor, whereas others load onto a separate "opposition to equality" factor. Because of conceptual and empirical ambiguities concerning the meaning and measurement of the construct of social dominance, some have interpreted it as a form of group justification, whereas others have treated it as synonymous with system justification. Sniderman, Crosby, and Howell (2000), for example, concluded that "the job of the social dominance measure" is to "assess the strength of the desire of some to enjoy the benefits of dominance over others" (p. 270), and they are by no means alone in this interpretation (e.g., Altemeyer, 1998; Pratto, Sidanius, Stallworth, \& Malle, 1994; Sidanius, 1993; Sidanius \& Pratto, 1993). Recently, the definition of social dominance orientation has shifted to make it more compatible with a system justification perspective. Sidanius, Levin, Federico, and Pratto (2001), for instance, described the concept as a "general desire for unequal relations among social groups, regardless of whether this means ingroup domination or ingroup subordination" (p. 312, italics omitted), which renders it much closer to system justification than group justification. Consistent with this interpretation, Overbeck, Jost, Mosso, and Flizik (2004) found that members of low-status groups with high SDO scores adopted system-justifying styles of acquiescence rather than group-justifying styles of resistance to the status quo (see also Jost \& Burgess, 2000).

As part of an increased effort to specify and, ultimately, formalize the central tenets of a system justification perspective, Jost and Hunyady (2002) listed 18 hypotheses that have been derived from this framework and reviewed empirical support for each of them. The hypotheses cover rationalization of the status quo, internalization of inequality (including outgroup favoritism and depressed entitlement), relations among ego, group, and system justification motives (including consequences for attitudinal ambivalence, self-esteem, and psychological wellbeing), and the reduction of ideological dissonance. The fact that each of these hypotheses has received at least some empirical support suggests that the first decade of system justification theory has been a productive one.

We organize our review of the relevant research around the hypotheses identified by Jost and Hunyady (2002) and two others addressed by Jost and Kay (in press; Kay \& Jost, 2003), but we will not devote equal space to each of them. Instead, we will emphasize and elaborate on those thematic issues that (a) are most relevant to political psychology, and (b) particularly distinguish a system justification perspective from related theories of social identification and social dominance. The themes we stress in this article are rationalization of the status quo; implicit, nonconscious outgroup favoritism; effects of political ideology on ingroup/outgroup favoritism; conflicts among ego, group, and system justification 
motives; evidence of enhanced system justification among the disadvantaged; and system-justifying effects of complementary stereotyping.

\section{Rationalization of the Status Quo}

According to McGuire and McGuire (1991), people engage in "sour grapes" and "sweet lemons" rationalizations by adjusting their preferences to fit with their expectations about what is likely to occur. Kay, Jimenez, and Jost (2002) elaborated on the McGuires' analysis of rationalization and offered the following hypothesis to distinguish its consequences from predictions derived from cognitive dissonance and social identity theories:

Hypothesis 1. People will rationalize the (anticipated) status quo by judging likely events to be more desirable than unlikely events, (a) even in the absence of personal responsibility, (b) whether those events are initially defined as attractive or unattractive, and (c) especially when motivational involvement is high rather than low.

In support, Kay et al. (2002) found that immediately before the 2000 U.S. presidential election, both Democrats and Republicans judged potential Bush and Gore presidencies to be more desirable as their perceived likelihood increased and less desirable as their perceived likelihood decreased. Stakeholders did not rationalize their own preferences or those of the political parties with which they identified. Rather, they rationalized the status quo even before it became the status quo, much as Democrats, Republicans, and independents all showed substantial increases in support for the Iraq war (as well as approval of the president's job performance and satisfaction with the direction of the country) immediately after President George W. Bush's announcement of war plans and the commencement of military action (Saad, 2003).

Another way in which people justify the way things are is by using stereotypes to differentiate between high- and low-status groups in such a way that inequality seems natural and appropriate (e.g., Jackman \& Senter, 1983). To eliminate actual differences between groups, Jost (2001) developed an experimental paradigm to assess the following hypothesis:

Hypothesis 2. People will use stereotypes to rationalize social and economic status differences between groups, so that the same target group will be stereotyped differently depending on whether it is perceived to be high or low in status.

Evidence provided by Jost (2001) and Jost and Burgess (2000) supported this hypothesis, revealing considerable ingroup derogation and outgroup elevation on 
status-justifying attributes when the ingroup was believed to be lower in social and economic status than the outgroup, and the opposite when the ingroup was believed to be higher in status.

If there is indeed a motive to defend and justify the status quo, as system justification theory holds, then people should be especially likely to use rationalizing stereotypes (and other means) to bolster the legitimacy of the prevailing system when it is threatened or attacked. Accordingly, Jost and Hunyady (2002) hypothesized:

Hypothesis 3. People will defend and justify the social system in response to threat by using stereotypes to differentiate between high- and lowstatus groups to a greater degree than when there is no threat.

Many of the social and psychological effects of the 9/11 terrorist attacks (Pyszczynski, Solomon, \& Greenberg, 2003)—including increased presidential support (Moore, 2001), governmental trust (Chanley, 2002), and stereotyping of Arab Americans (Goodwin \& Devos, 2002) — may be attributable to heightened needs to defend and justify the system against threat, although it is difficult to distinguish among personal, group, and system-level threats in this case (e.g., Huddy, Feldman, Capelos, \& Provost, 2002).

On the assumption that people would further rationalize the status quo by accepting and even bolstering weak justifications for inequality among groups, Haines and Jost (2000) argued:

Hypothesis 4. Providing explanations (or pseudo-explanations) for status or power differences between groups will (a) increase the use of stereotypes to rationalize differences, and (b) lead members of disadvantaged groups to express more positive (relative to negative) affect concerning their situation.

Hypothesis 5. Members of disadvantaged groups will misremember explanations for their powerlessness as being more legitimate than they actually were.

Both hypotheses were supported. Even placebic explanations led members of a disadvantaged group to feel better and to ascribe favorable characteristics to members of an outgroup that had power over them (see also Kappen \& Branscombe, 2001). A memory bias indicated that people were more likely than would be expected by chance to falsely recall that neutral and illegitimate explanations for the power differences were in fact legitimate.

None of the myriad ways in which people imbue the status quo with justification and legitimacy follow from theories of social identification or social dominance. Rather, hypotheses concerning the varied manner and considerable extent to which people actively rationalize the status quo must be derived from a perspective that takes system justification tendencies seriously (see also Schmader, Major, Eccleston, \& McCoy, 2001). 


\section{The Importance of Outgroup Favoritism}

Jost and Banaji (1994) argued that by stressing the ubiquity of ingroup favoritism, social identity theory failed to account adequately for the degree of stereotype consensus across group boundaries and the prevalence of outgroup favoritism among members of low-status groups. In advancing this criticism, we joined several others, including Sidanius (1993) and even a few social identity theorists (Hewstone \& Jaspars, 1984; Hewstone \& Ward, 1985; Hinkle \& Brown, 1990 ), some of whom now argue that social identity theory has no problem handling outgroup favoritism (see Brown, 2000a; Rubin \& Hewstone, 2004). In proposing system justification theory as an alternative, Jost and Banaji (1994) hypothesized that members of both high- and low-status groups engage in thoughts, feelings, and behaviors that reinforce and legitimate existing social systems, and that outgroup favoritism is one such example of the legitimation of inequality between groups. Outgroup favoritism refers to the expression of an evaluative preference for members of a group to which one does not belong (see Jost et al., 2002). The argument is not that people have a special motivation to favor the outgroup merely because it is an outgroup. Rather, outgroup favoritism is seen as one manifestation of the tendency to internalize and thus perpetuate the system of inequality. Its prevalence contradicts the common but false assumption derived from social identity theory that "members of actual low-status groups, whose group identity is chronically threatened by their relative inferiority to higher status groups, evaluate out-groups most negatively" (Leach et al., 2003, p. 933).

\section{Objections to Taking Outgroup Favoritism Seriously}

Several different reasons have been offered for downplaying the significance of outgroup favoritism among low-status group members and for rejecting the possibility that it reflects system justification. The first is that outgroup favoritism may be due to demand characteristics. This was the position taken by Mullen et al. (1992), who dismissed the fact that $85 \%$ of the low-status experimental groups included in their meta-analysis exhibited outgroup favoritism (see Jost, 2001). Mullen et al. discounted the experimental evidence on the grounds that the studies used "artificial groups" and "a concentration on transitory, task-specific conceptualizations of status" (p. 119). To address this issue, Jost (2001) summarized several studies in which perceived socioeconomic success was experimentally manipulated in the context of real-world group memberships and found that outgroup favoritism was still the dominant response of members of low-status groups.

A second criticism is that most evidence of outgroup favoritism has been on "status-relevant" dimensions of comparison, which suggests that perceptions of relative inferiority may be largely accurate. Brewer and Miller (1996), for instance, argued that "considering this factor, the effect should probably not be 
labeled a 'bias' at all” (p. 95). In responding to this issue, Overbeck et al. (2004) showed that members of low-status groups who score high on SDO (and therefore actively reject egalitarian alternatives to the status quo) exhibit outgroup favoritism even on status-irrelevant traits, indicating that they have a generalized sense of inferiority. Behavioral evidence provided by Jost et al. (2002) also establishes that outgroup favoritism is not restricted to status-relevant stereotypic traits.

A third, related objection is that outgroup favoritism occurs "only" when members of low-status groups are "constrained" by "social reality" to accept the legitimacy and stability of the status quo, before they have the chance to adopt one of several identity enhancement strategies: individual exit/mobility, social creativity, or social competition (Tajfel \& Turner, 1986). With regard to the behavior of members of disadvantaged groups, social identity theory clearly aims to focus on how people move "from social stability to social change" (Tajfel, 1981), from "passive acceptance to collective protest" (Wright, Taylor, \& Moghaddam, 1990), and from "social reality to social resistance" (Spears et al., 2001) whenever circumstances leave the possibility open. ${ }^{3}$ The main problem with this formulation is that it underestimates the strength of system justification motives to rationalize the status quo and leave everything as it is. Consequently, the theory is overly optimistic about prospects for social change (see Reicher, 2004).

A fourth objection is that outgroup favoritism reflects public impression management rather than genuine, private internalization of inferiority (e.g., Scott, 1990). In their critique of system justification theory, for example, Spears et al. (2001) argued that "the resistance of low status social groups to their so-called 'inferiority' may have been somewhat underestimated, often because we have taken expressions of outgroup bias (and the expression of ingroup bias) at face value" (p. 334). The suspicion that public avowals should not be taken "at face value" is also consistent with self-categorization accounts that underscore the strategic, rhetorical aspects of intergroup relations (e.g., Reicher \& Levine, 1994). Although most experimental studies allow for participants to make private rather than public responses, we certainly agree that there are some limitations associated with the use of explicit measures of ingroup and outgroup favoritism (see Jost et al., 2002). Thus, Jost and Hunyady (2002) considered the following hypothesis:

Hypothesis 6. Members of low-status groups will exhibit outgroup favoritism even on (a) open-ended, nonreactive, qualitative measures, and (b) implicit, nonconscious cognitive, affective, and behavioral measures.

\footnotetext{
${ }^{3}$ This treatment acknowledges the phenomenon of system justification, but the account is a passive one: People perceive legitimacy and stability when they have no other choice or "alternative." System justification theory, by contrast, focuses on the active social, cognitive, and motivational rejection of alternatives to the status quo and the fact that even members of disadvantaged groups are motivated to perceive the system as legitimate and stable.
} 
Furthermore, the social desirability/impression management argument offered by social identity theorists can be turned on its head. There are sound reasons to think that the expression of ingroup (rather than outgroup) favoritism would be encouraged by conformity to social norms, especially among members of commonly devalued groups. Miller (1999), for instance, argued that self-interest is a powerful social norm and that people often behave in self-interested (and groupinterested) ways in order to comply publicly with the expectations of others. Miller and Ratner (1998) showed that people consistently overestimate the degree to which support for social policies is actually related to individual and collective self-interest. Studies by Ratner and Miller (2001) demonstrated further that people are socially sanctioned (and expect to be sanctioned) for violating assumptions of self-interest by taking action on behalf of a cause in which they have no stake or by taking stake-incongruent action. Thus, an analysis of social norms reveals that there are often strong pressures to exaggerate self-interested and group-interested behavior.

We expect that social pressure to express ingroup favoritism would be even more prevalent in groups that have traditionally been targets of discrimination and prejudice than in other groups. Prescriptive norms to avoid "identification with the oppressor" and the "Uncle Tom" syndrome can be intense (see, e.g., Scheepers, Branscombe, Spears, \& Doosje, 2002). Few observers of contemporary American society would draw the conclusion that African Americans (and other racial and ethnic minorities) generally accept that unequal race relations are legitimate at an explicit, conscious level of awareness. Nonetheless, many recent studies reveal that when intergroup biases are measured at an implicit level, members of low-status minority groups (including African Americans) commonly fail to exhibit ingroup bias and show preferences for higher-status outgroupseven when these preferences are soundly rejected at an explicit, conscious level. ${ }^{4}$

Because there are also relatively strong normative pressures for members of advantaged groups to avoid being seen as prejudiced or discriminatory (e.g., Dovidio \& Gaertner, 1986), we would expect them to exhibit greater ingroup favoritism on implicit measures than on explicit measures. Putting the above observations concerning low- and high-status groups together, we therefore propose the following interaction hypothesis:

Hypothesis $6^{\prime}$. Members of low-status groups will be more likely to exhibit outgroup favoritism on implicit measures than on explicit measures, whereas members of high-status groups will be more likely to exhibit ingroup favoritism on implicit measures than on explicit measures.

\footnotetext{
${ }^{4}$ Another phenomenon that likely captures a system-justifying form of implicit outgroup favoritism is the tendency for African Americans to show preferences for lighter-skinned blacks over darkerskinned blacks (Hill, 2002).
} 
Because Hypotheses 6 and $6^{\prime}$ address key issues that differentiate social identity and system justification perspectives, we will summarize empirical evidence bearing on these hypotheses in some detail.

\section{Implicit Assessment of Intergroup Bias}

Objections against interpreting outgroup favoritism as an indicator of internalization may be addressed empirically with the use of implicit, nonconscious measures of favoritism. Because implicit responses are assumed to be automatic and uncontrollable, the use of implicit measures obviates concerns about strategic impression management (e.g., Greenwald \& Banaji, 1995). In addition, implicit measures may tap cognitions that are not necessarily available to conscious introspection and therefore may differ considerably from explicit, controllable responses. These features of implicit evaluations provide methodological leverage for investigations of outgroup favoritism (see also Jost et al., 2002). For example, implicit measurement may reveal associations that are unwanted or otherwise inconsistent with people's explicit views of themselves and their groups (such as unfavorable evaluations of their own group). In addition, implicit evaluations may guide perception, judgment, and behavior through mechanisms that are completely outside of conscious awareness, thereby providing a particularly insidious means by which system-justifying effects influence members of disadvantaged groups.

Many (but not all) of the studies that are most useful for assessing implicit ingroup and outgroup favoritism have used Greenwald, McGhee, and Schwartz's (1998) Implicit Association Test (IAT). This procedure typically uses very abstract evaluations of social groups (e.g., good vs. bad, pleasant vs. unpleasant associations); thus, evidence of outgroup favoritism on such measures does not merely reflect status-relevant stereotypes or the consensual demands of social reality. By focusing on implicit measures, we are not suggesting that members of low-status groups never show outgroup favoritism on explicit measures; we know that they often do (e.g., Jost, 2001; Jost \& Banaji, 1994). Our review focuses specifically on groups that, according to social identity theory, would be least likely to show outgroup favoritism on explicit measures. We find that even when members of these low-status groups express ingroup favoritism on explicit measures, many of them still exhibit outgroup favoritism on implicit measures.

\section{Summary of Existing Research}

Investigations of implicit ingroup and outgroup favoritism have primarily assessed attitudes of various age and ethnic groups. Banaji, Greenwald, and Rosier (1997) were among the first to compare implicit and explicit levels of ingroup and outgroup favoritism among groups differing in racial/ethnic status in a study of undergraduates at Yale University. Their results indicated that on an explicit 
"feeling thermometer" measure, African American students expressed significantly more favorable (or "warm") attitudes toward their own group than did European American students. On the implicit (IAT) measure, however, the pattern was reversed: African Americans showed less favorable attitudes toward their own group in comparison with European Americans (see also Livingston, 2002).

It is possible that these results were limited to a highly unusual sample: college students at Yale (a predominantly white and Asian environment). Nosek, Banaji, and Greenwald (2002a) confirmed with much larger and more diverse samples from a demonstration website (now available at http://implicit. harvard.edu) that the original findings were robust and widespread. Results based on 103,316 European American respondents and 17,510 African American respondents indicated that African Americans displayed stronger explicit ingroup favoritism $(d=0.80)$ than did European Americans $(d=0.59)$. Implicitly, however, European Americans showed stronger ingroup favoritism $(d=0.83)$ than did African Americans, who actually showed outgroup favoritism $(d=-0.16)$.

The website also provided data on a measure of age bias (against older people), which remains among the largest and most consensual of implicit biases against a social group in the United States, even stronger than racial biases (Levy \& Banaji, 2002; Nosek et al., 2002a). On both implicit and explicit measures, attitudes toward the elderly are never more favorable than attitudes toward the young. Explicit attitudes do vary as a function of age, with less negative attitudes expressed toward the elderly among older respondents. Implicit attitudes bear no such relationship to age. Implicit ageism remains equivalently strong across the range of respondent ages (see Nosek et al., 2002a).

A number of other published and unpublished studies have investigated implicit and explicit group biases among groups that differ on racial, ethnic, and other status dimensions. Spicer and Monteith (2001) showed that between 50\% and $65 \%$ of African American students at the University of Kentucky exhibited implicit outgroup bias in favor of European Americans. Ashburn-Nardo, Knowles, and Monteith (2003) similarly found that $60 \%$ of African American respondents showed a pro-white outgroup bias on an implicit measure, although they expressed highly favorable ingroup attitudes on explicit measures. Lane, Mitchell, and Banaji (2003) obtained substantial evidence of implicit outgroup favoritism among members of lower-status (vs. higher-status) residential colleges at Yale, even though assignment to living quarters was widely known to be randomly determined.

Uhlmann, Dasgupta, Elgueta, Greenwald, and Swanson (2002) investigated implicit skin color biases among Latinos in the United States and Chile. On IAT measures, Latinos tended to express outgroup favoritism in favor of whites (with $d$ s ranging from 0.13 to -0.67 ), and dark-skinned morenos expressed outgroup favoritism (with $d$ s ranging from -0.60 to -0.85 ) in favor of light-skinned blancos (who also expressed ingroup favoritism relative to morenos, with $d$ s ranging from 0.85 to 1.22). On explicit measures, members of all groups tended to exhibit 
weak to moderate levels of ingroup favoritism (with $d$ s ranging from -0.10 to 0.59 ).

Rudman, Feinberg, and Fairchild (2002) rank-ordered high- and low-status groups in terms of the magnitude of the perceived status gap that separated them. They found that the largest status gaps (rich vs. poor, slim vs. overweight) were accompanied by relatively strong ingroup favoritism on the part of high-status group members (rich, $d=1.73$; slim, $d=0.78$ ) and relatively strong outgroup favoritism on the part of low-status group members (poor, $d=-1.14$; overweight, $d=-0.34$ ) on implicit (but not explicit) measures. Smaller status gaps (whites vs. Asians, Christians vs. Jews) were accompanied by strong implicit ingroup favoritism on the part of high-status group members (whites, $d=0.92$; Christians, $d=1.22$ ) and relatively weak ingroup favoritism on the part of low-status group members (Asians, $d=0.27$; Jews, $d=0.41$ ).

Jost et al. (2002) found that more than twice as many members of a lowstatus group (San Jose State University students) exhibited implicit outgroup favoritism on an affective IAT measure as did members of the high-status group (Stanford University students). Among SJSU students (but not Stanford students), implicit stereotyping of the two groups (Stanford as more academic, SJSU as more involved in "extracurricular" activities) was associated with implicit outgroup favoritism on the affective measure. Implicit outgroup favoritism on the affective measure was also associated with lowered implicit self-esteem at the individual level. In a second study, Jost et al. (2002) found that whites, Latinos, and Asian American students all preferred to participate in a "getting acquainted" study with a stranger whom they believed to be white at a rate that was significantly higher than would be expected by chance, and they avoided minority interaction partners at a rate that was higher than would be expected by chance. These findings challenge common assumptions of similarity and homophily in sociology and psychology that people prefer to interact with those who are similar and who share the same group memberships.

In a third study, which included an analysis of birth records available on the Internet, Jost et al. (2002) found that parents were more than twice as likely to name their baby boys using the fathers' initials than to name their baby girls using the mothers' initials. Parents were also more likely to post a birth announcement in the local newspaper for boys than for girls. This research supports the existence of "implicit paternalism" as yet another (consensual) form of nonconscious system-justifying bias.

To investigate implicit biases affecting other behavioral outcomes, Correll, Park, Judd, and Wittenbrink (2002) carried out video simulations of the splitsecond decisions made by police officers under ambiguity. Research participants were instructed to determine as quickly and accurately as possible whether white and black target persons were armed (in which case they should decide to "shoot") or unarmed (in which case they should "not shoot"). One of the studies included African American research participants as well as European Americans, and the 
results from this study indicated that African Americans were just as likely as European Americans to evince an implicit anti-black racial bias. Specifically, members of both groups were faster to decide to shoot black armed targets and faster to decide not to shoot white unarmed targets. Thus, consensually shared system-justifying biases have been found to influence highly consequential behavioral decisions outside of conscious control.

\section{New Data From Demonstration Websites}

New data from three measures available to the public at a demonstration website (http://tolerance.org) provided an opportunity to extend the existing evidence concerning implicit and explicit ingroup and outgroup favoritism. In this section and the next, we use these additional data to replicate and extend previous findings with regard to three different comparisons between members of advantaged and disadvantaged groups: white versus black, young versus old, and straight versus gay. ${ }^{5}$

Racial attitudes were compared among black and white respondents. Replicating previous demonstrations, African American respondents showed stronger explicit ingroup favoritism $(d=0.79, n=2,048)$ than did European American respondents $(d=0.62, n=15,110)$, although both clearly showed explicit preferences for their own group. On implicit measures, European Americans showed ingroup favoritism $(d=1.06, n=15,229)$, but African Americans did not $(d=$ $0.04, n=2,011$ ). As shown in Figure 1, a larger percentage of European Americans expressed ingroup favoritism on implicit measures $(78.4 \%)$ than on explicit measures $(51.1 \%)$, whereas a larger percentage of African Americans expressed ingroup favoritism on explicit measures (65.4\%) than on implicit measures (40.1\%). When attitudes were measured implicitly, 39.3\% of African Americans showed outgroup favoritism, which is about the same proportion that showed ingroup favoritism. In sum, African Americans_a disadvantaged group relative to European Americans-showed strong ingroup favoritism explicitly, but not implicitly. European Americans, by contrast, showed strong ingroup favoritism whether measured explicitly or implicitly.

\footnotetext{
5 Procedures and methodological issues for web-based data collection, analysis, and interpretation are discussed in detail by Nosek, Banaji, and Greenwald (2002a, 2002b). Data samples were all of the respondents from the following date ranges for each of the intergroup comparisons: race (15 November 2001-5 February 2003), age (20 March 2001-5 February 2003), and sexual orientation (18 March 2002-29 October 2002). Explicit measures for all three tasks consisted of a difference score between individual warmth (feeling thermometer) ratings on 11-point scales toward each of the two target groups (e.g., black-white). Implicit measures were the Implicit Association Test (IAT; Greenwald et al., 1998) assessing relative preference for one target group versus the other. Data preparation and analysis of the implicit measures proceeded according to the scoring algorithm procedures described by Greenwald, Nosek, and Banaji (2003) with the following features: Error latencies were replaced by block means plus a penalty of 600 milliseconds, and trial latencies below 400 milliseconds were deleted.
} 


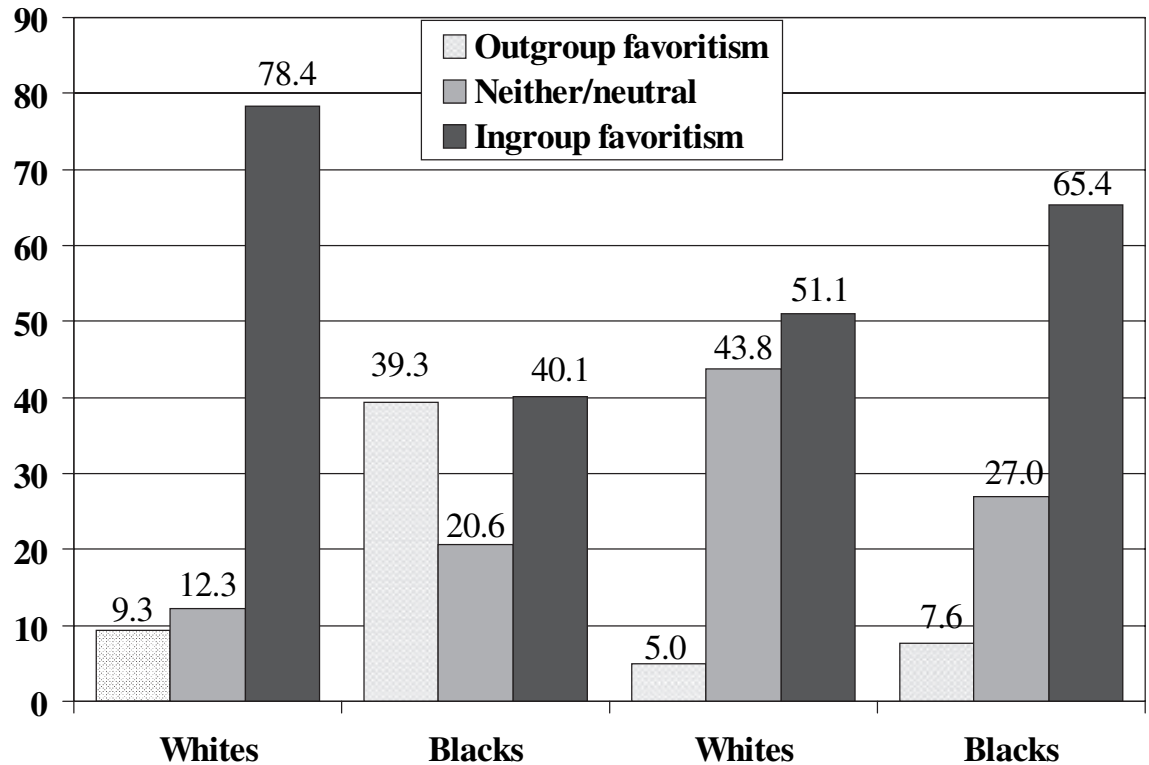

Implicit Attitudes

Explicit Attitudes

Figure 1. Percentages of European Americans (whites) and African Americans (blacks) expressing ingroup favoritism, neutrality, and outgroup favoritism on implicit and explicit attitudes. For the measure of explicit attitudes, it was possible for participants to report being neutral or nonbiased by rating both groups equally. To create a comparable neutral range for the measure of implicit attitudes, we calculated the number of standard deviations on the explicit scale needed to go from 0 (no bias) to \pm 0.5 (slight bias) and then calculated IAT scores reflecting the same number of standard deviations away from the zero point. Within that range, a person is said to exhibit neither ingroup nor outgroup favoritism.

A second task compared age attitudes among young and old respondents. For the purposes of analysis, respondents who were 50 years of age or under were classified as "young." On explicit measures, young people reported ingroup favoritism $(d=0.34, n=13,710)$ and older people showed a weak pattern of outgroup favoritism $(d=-0.05, n=868)$. On implicit measures, young people demonstrated strong ingroup favoritism $(d=0.99, n=12,610)$ and older people exhibited strong implicit outgroup favoritism $(d=-0.87, n=815)$. As shown in Figure 2, older respondents were almost as likely to express implicit outgroup favoritism $(72.0 \%)$ as young participants were to express implicit ingroup favoritism $(75.5 \%)$.

\footnotetext{
${ }^{6}$ Because the 50-year-old cutoff point was determined arbitrarily, we conducted additional analyses including only the oldest respondents in the sample (e.g., >70); results were very similar to those reported in the text.
} 


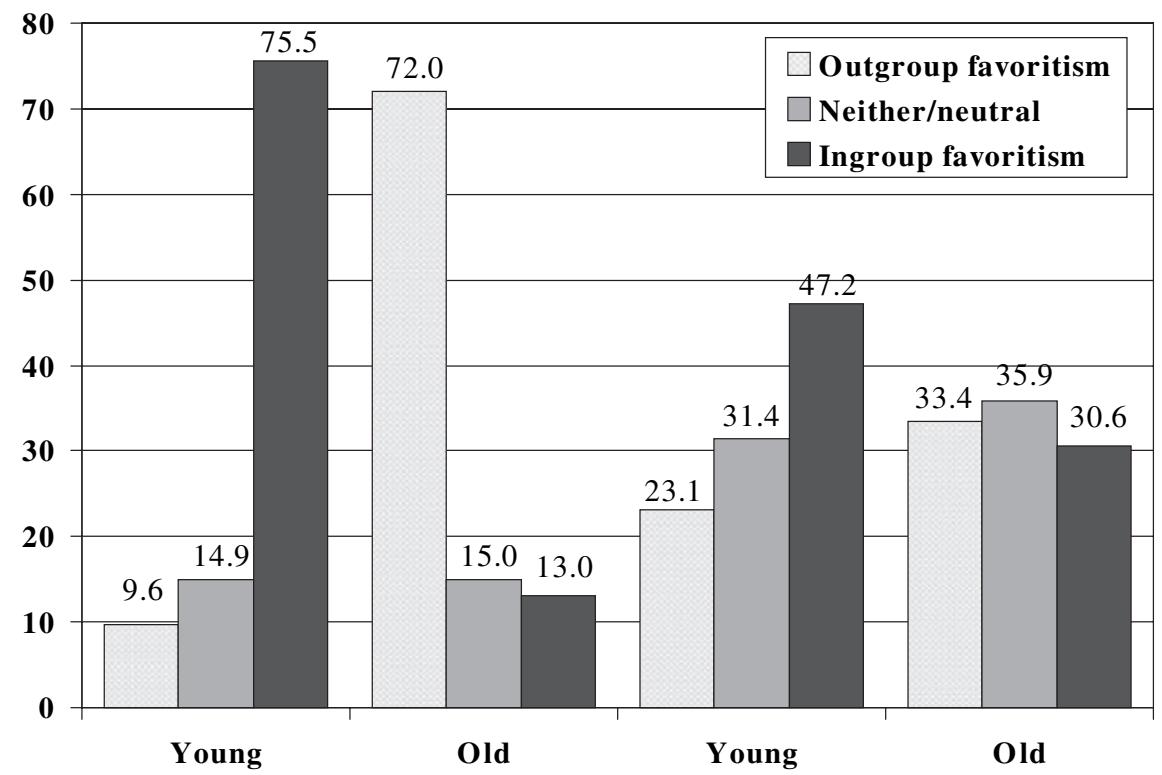

\section{Implicit Attitudes}

Explicit Attitudes

Figure 2. Percentages of young and old respondents expressing ingroup favoritism, neutrality, and outgroup favoritism on implicit and explicit attitudes. Expressions of neutrality were measured as described in the legend of Figure 1.

The final data set culled from the demonstration website allowed us to compare implicit and explicit intergroup biases pertaining to sexual orientation. Both straight and gay respondents showed relatively strong explicit ingroup preferences (straight, $d=0.84, n=14,329$; gay, $d=0.64, n=3,316$ ). On implicit measures, however, only straight participants showed strong ingroup preferences ( $d=1.10, n=14,619)$. Gay and lesbian respondents on average exhibited only slight implicit ingroup favoritism $(d=0.11, n=3,354)$. As shown in Figure 3 , a very strong majority $(81.0 \%)$ of straight participants expressed ingroup favoritism on implicit measures, but the responses of more than a third $(37.5 \%)$ of gay participants $(37.2 \%$ of lesbians and $38.2 \%$ of gay men) revealed implicit preferences for the straight outgroup.

This review of published and new data supports Jost and Banaji's (1994) contention that members of disadvantaged groups are especially likely to exhibit outgroup favoritism on implicit measures, insofar as such measures minimize social desirability concerns and vitiate the need (or ability) for potentially painful conscious acknowledgment of inferiority (to oneself and to others). These findings also consistently support Hypothesis 6'. Specifically, members of low-status 


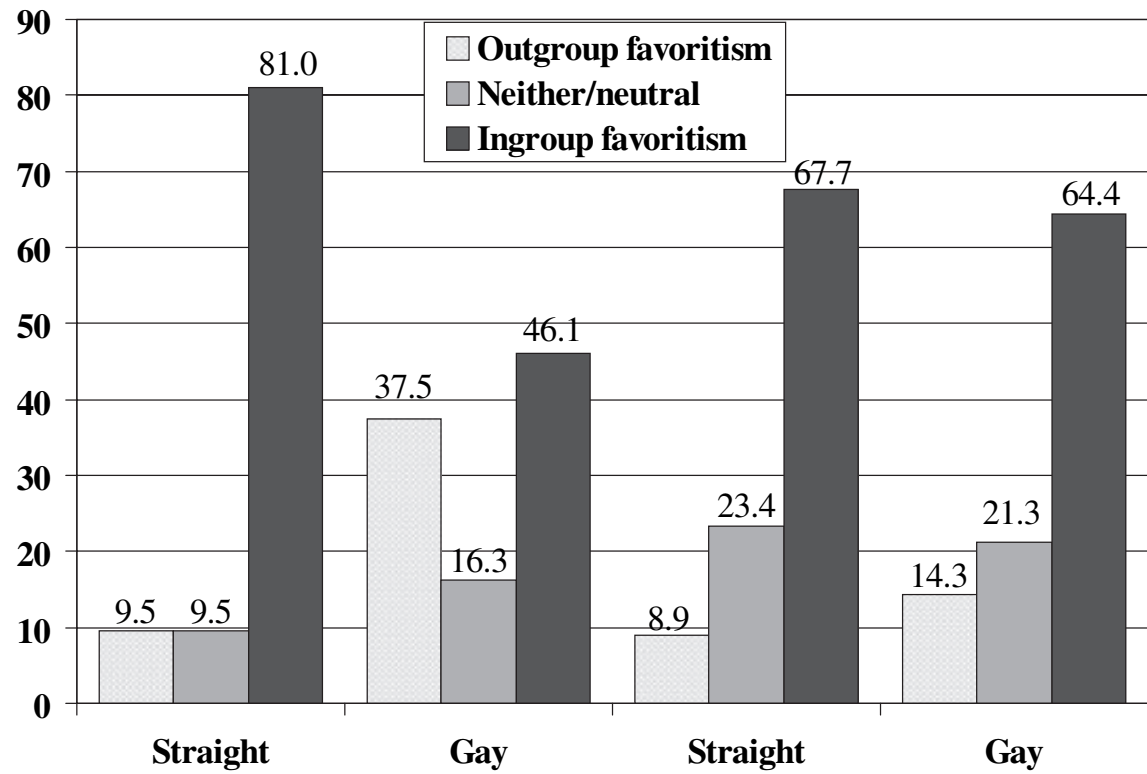

Implicit Attitudes

Explicit Attitudes

Figure 3. Percentages of heterosexual (straight) and homosexual (gay) respondents expressing ingroup favoritism, neutrality, and outgroup favoritism on implicit and explicit attitudes.

Expressions of neutrality were measured as described in the legend of Figure 1.

groups exhibit outgroup favoritism with greater frequency on implicit measures than on explicit measures, whereas members of high-status groups exhibit ingroup favoritism with greater frequency on implicit measures than on explicit measures.

\section{Political Ideology as a Moderator of Intergroup Bias}

According to system justification theory, the degree of (explicit) intergroup bias should be moderated by the degree to which the status quo is perceived as legitimate and justified. Specifically, Jost and Hunyady (2002) noted:

Hypothesis 7. As the perceived legitimacy of the system increases, (a) members of high-status groups will exhibit increased ingroup favoritism, and (b) members of low-status groups will exhibit increased outgroup favoritism.

This interaction hypothesis differs from the main-effect prediction of Turner and Brown (1978), who proposed that groups "with illegitimate status relations would 
display more ingroup bias than those with legitimate status relations" (p. 210) because of status insecurity, regardless of the status of the ingroup. Although Hornsey, Spears, Cremers, and Hogg (2003) have found support for the maineffect hypothesis, several other studies have obtained the crossover interaction pattern and no main effect (see Jost, 2001; Jost \& Burgess, 2000; Levin, Sidanius, Rabinowitz, \& Federico, 1998; Major et al., 2002).

A conceptually related hypothesis is that system justification tendencies in general should moderate the expression of ingroup and outgroup favoritism:

Hypothesis 8. As system justification tendencies increase, (a) members of high-status groups will exhibit increased ingroup favoritism, and (b) members of low-status groups will exhibit increased outgroup favoritism.

Jost and Thompson (2000) developed an economic system justification scale to measure the degree to which people perceive economic inequality to be fair, legitimate, and necessary. They found that scores on the scale predicted enhanced ingroup favoritism (on a feeling thermometer measure) among European Americans but not among African Americans. A subsequent study indicated that economic system justification was also associated with increased ingroup favoritism among northern Italians (a high-status group) and increased outgroup favoritism among southern Italians (a low-status group; see Jost \& Hunyady, 2002, pp. 136-138).

Jost et al. (2003a) argued that (right-wing) political conservatism is a form of system justification, insofar as it provides moral and intellectual support for the status quo by (a) resisting change and (b) rationalizing the existence of inequality. If this assumption is correct, then it follows from the foregoing that:

Hypothesis $8^{\prime}$. As political conservatism increases, (a) members of highstatus groups will exhibit increased ingroup favoritism, and (b) members of low-status groups will exhibit increased outgroup favoritism.

Consistent with this formulation, Levin et al. (1998) reported that conservatism was associated with significant levels of ingroup favoritism among European and Asian American respondents and with significant levels of outgroup favoritism among Latinos and African Americans. Similarly, Jost and Thompson (2000, study 4) administered measures of political ideology and intergroup bias; conservatism was indeed associated with increased ingroup favoritism among European Americans $(d=0.30, n=342)$ and increased outgroup favoritism among African Americans $(d=-0.43, n=105)$. Jost et al. (2001) analyzed national survey data from Italy and found that northern Italians expressed stronger ingroup favoritism as they held increasingly right-wing political opinions, whereas southern Italians expressed (slightly) stronger outgroup favoritism as they held increasingly rightwing political opinions. 


\section{Data From the Demonstration Website}

Data from the IAT demonstration website can also be used to investigate relations between political orientation and ingroup and outgroup favoritism. Selfreported political orientation was included in the demographic questionnaire for each of the three web-based tasks described previously. Specifically, participants located themselves on a 7-point scale ranging from "extremely liberal" $(-3)$ to "extremely conservative" (3). We conducted a series of regression analyses for each of the three intergroup comparisons (white-black, young-old, and gaystraight) for measures of both implicit and explicit intergroup bias. For each comparison, Model 1 included variables for group membership, political conservatism, and their interaction. Model 2 included these variables, a control variable for explicit attitudes when predicting implicit attitudes, and a control variable for implicit attitudes when predicting explicit attitudes to show that the relationship held for each measurement type independently of the other. Model 3 included the variables from Model 1 as well as demographic control variables for age, sex, and education to show that the relationship persisted after controlling for other demographic variables. For the young-old comparison, no main or interaction effects of political ideology were observed, and so we will not discuss these results further. For the other two comparisons, however, group membership and political ideology consistently interacted with one another to predict both implicit and explicit attitudes in all analyses.

Regression results for the white-black comparisons are summarized in Table 2. Considering the significant effect of the interaction between group membership and political ideology separately for racial groups, we find that conservatism exerts opposite effects on ingroup favoritism for European and African Americans. For European Americans, political conservatism was positively and significantly associated with ingroup favoritism on both implicit $(d=0.26, n=10,644)$ and explicit measures $(d=0.52, n=10,527)(p<.001$ in both cases $)$. For African Americans, increasing conservatism was associated with increased outgroup favoritism on the explicit measure $(d=-0.20, n=1,437, p<.001)$ and, nonsignificantly, on the implicit measure $(d=-0.06, n=1,464)$. Means are shown in Figure 4.

Results are even more compelling for the gay-straight comparison (see Table 3 ). For straight respondents, political conservatism was strongly predictive of a pro-straight/anti-gay ingroup bias on both implicit $(d=0.56, n=14,038)$ and explicit measures $(d=0.98, n=13,792)$. For gay and lesbian respondents, however, conservatism was associated with a pro-straight/anti-gay outgroup bias on implicit ( $d=-0.35, n=3,264)$ and explicit measures $(d=-0.41, n=3,233)$. Means are shown in Figure 5. Thus, studies involving race, ethnicity, regional status differences, and sexual orientation consistently support the crossover interaction hypothesis that as political conservatism increases, members of high-status groups tend to exhibit increased ingroup favoritism, whereas members of low- 
Table 2. Results of Regression Analyses for Racial Comparison

\begin{tabular}{lccc}
\hline & Model 1 & Model 2 & Model 3 \\
\hline Implicit attitude & & & .00 \\
Education & & & $-.06^{* * *}$ \\
Sex & & & $-.03^{* *}$ \\
Age & & $.25^{* * *}$ & \\
Explicit attitude & $-.31^{* * *}$ & $-.33^{* * *}$ & $-.31^{* * *}$ \\
Group membership & $.04^{* *}$ & $.03^{*}$ & $.04^{* *}$ \\
Political conservatism & $-.07^{* * *}$ & $-.03^{*}$ & $-.07^{* * *}$ \\
Group $\times$ conservatism & $10 \%$ & $16 \%$ & $11 \%$ \\
Adjusted $R^{2}$ & & & -.01 \\
Explicit attitude & & & $-.08^{* * *}$ \\
Education & & & .00 \\
Sex & & $.26^{* * *}$ & $.07^{* * *}$ \\
Age & $.07^{* * *}$ & $.15^{* * *}$ & $.05^{* * *}$ \\
Implicit attitude & $.06^{* * *}$ & $.05^{* *}$ & $-.18^{* * *}$ \\
Group membership & $-.19^{* * *}$ & $-.17^{* * *}$ & $7 \%$ \\
Political conservatism & $7 \%$ & $13 \%$ & \\
Group $\times$ conservatism & & & \\
Adjusted $R^{2}$ & & & \\
\hline
\end{tabular}

Note. Entries are standardized regression coefficients ( $\beta \mathrm{s})$. Group membership was coded $-1=$ whites, $1=$ blacks. Respondent sex was coded $0=$ male, $1=$ female.

$* p<.05, * * p<.01, * * * p<.001$.

Table 3. Results of Regression Analyses for Sexual Orientation Comparison

\begin{tabular}{lccc}
\hline & Model 1 & Model 2 & Model 3 \\
\hline Implicit ingroup/outgroup favoritism & & & \\
Education & & & $-.02^{* *}$ \\
Sex & & & $-.09^{* * *}$ \\
Age & & $.31^{* * *}$ & $-.02^{* *}$ \\
Explicit attitude & $-.46^{* * *}$ & $-.38^{* * *}$ & $-.46^{* * *}$ \\
Group membership & $.02^{*}$ & -.02 & .01 \\
Political conservatism & $-.25^{* * *}$ & $-.14^{* * *}$ & $-.25^{* * *}$ \\
Group $\times$ conservatism & $18 \%$ & $25 \%$ & $18 \%$ \\
Adjusted $R^{2}$ & & & $-.06^{* * *}$ \\
Explicit ingroup/outgroup favoritism & & & $-.11^{* * *}$ \\
Education & & & $-.03^{* *}$ \\
Sex & & $.30^{* * *}$ & \\
Age & $-.28^{* * *}$ & $-.14^{* * *}$ & $-.28^{* * *}$ \\
Implicit attitude & $.14^{* * *}$ & $.13^{* * *}$ & $.11^{* * *}$ \\
Group membership & $-.36^{* * *}$ & $-.28^{* * *}$ & $-.36^{* * *}$ \\
Political conservatism & $19 \%$ & $27 \%$ & $21 \%$ \\
Group $\times$ conservatism & & & \\
Adjusted $R^{2}$ & & & \\
\hline
\end{tabular}

Note. Entries are standardized regression coefficients ( $\beta$ s). Group membership was coded $-1=$ straight, $1=$ gay. Respondent sex was coded $0=$ male, $1=$ female.

$* p<.05, * * p<.01, * * * p<.001$. 
(A)

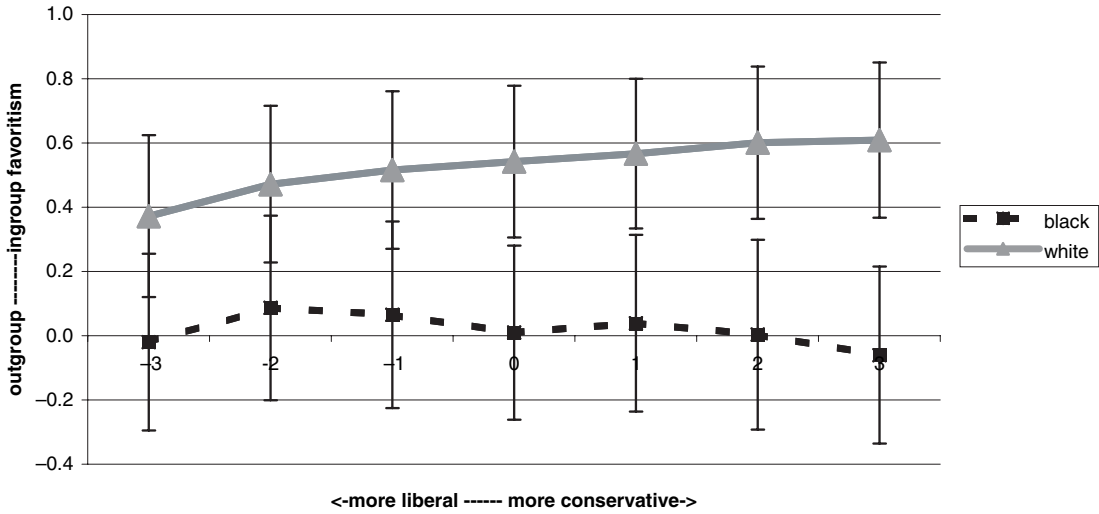

(B)

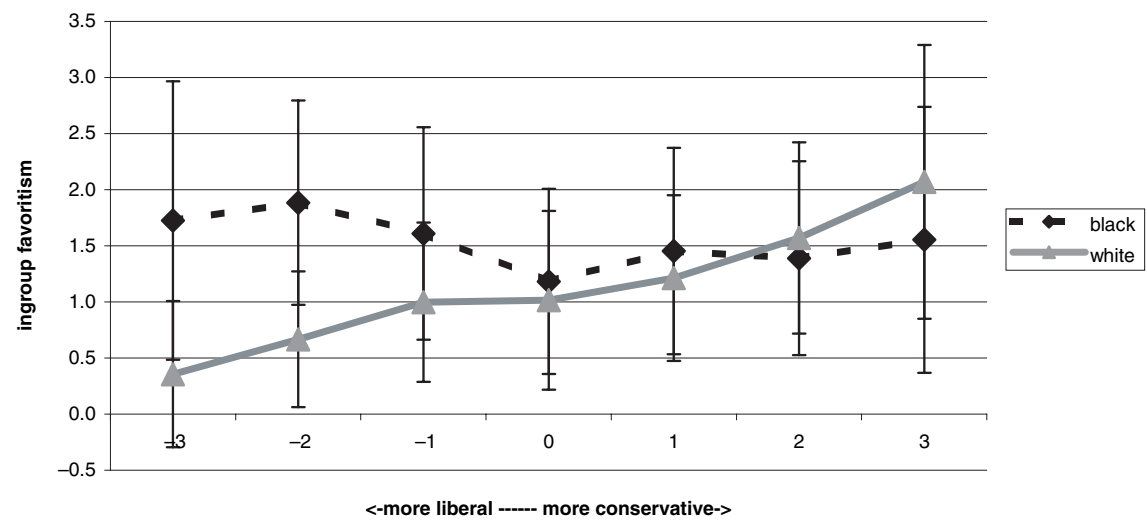

Figure 4. Relations between political ideology and ingroup/outgroup favoritism on implicit and explicit measures as a function of race. (A) Implicit ingroup/outgroup favoritism; (B) explicit ingroup/outgroup favoritism. Error bars indicate one standard deviation above and below the mean.

status groups exhibit increased outgroup favoritism. Among other things, this evidence contradicts the content-free assumptions of social identity theory as applied to ideology and political group membership, including the claim by Turner and Reynolds (2003) that "the right-wing versus left-wing continuum of political thought does not correlate well with being simply for or against group inequalities" (p. 202). Indeed, right-wing conservatism is consistently associated with acceptance (rather than rejection) of inequality across many different contexts (see also Jost et al., 2003a, 2003b). 


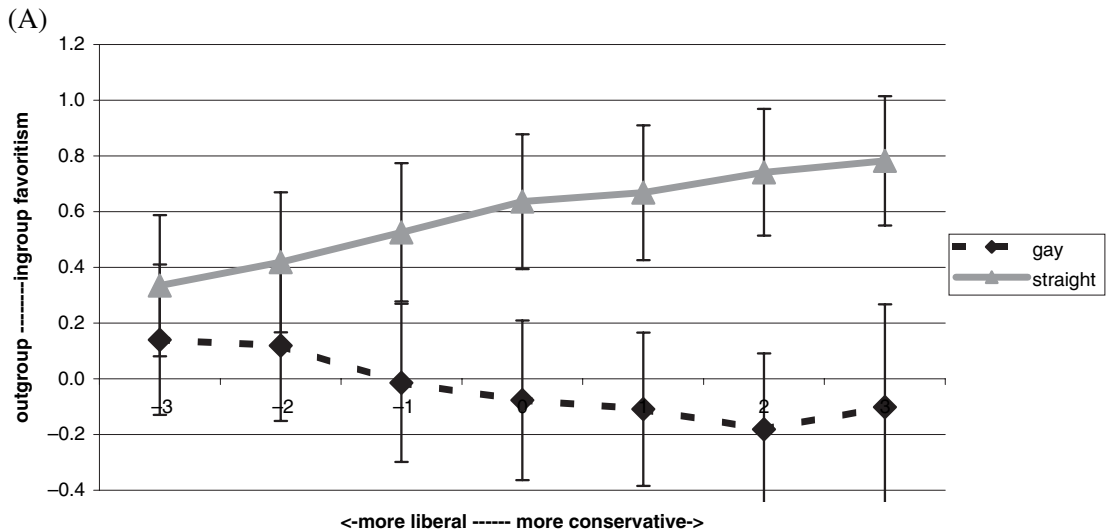

(B)

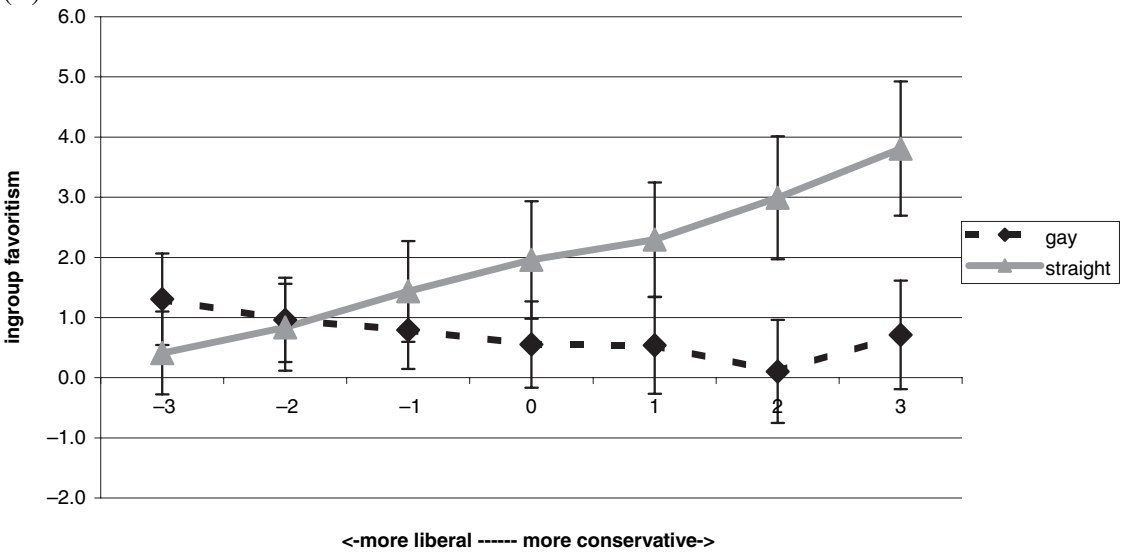

Figure 5. Relations between political ideology and ingroup/outgroup favoritism on implicit and explicit measures as a function of sexual orientation. (A) Implicit ingroup/outgroup favoritism; (B) explicit ingroup/outgroup favoritism. Error bars indicate one standard deviation above and below the mean.

\section{Depressed Entitlement Among the Disadvantaged}

According to Major (1994), the oft-noted tendency for women to feel that they deserve lower wages than men do is another (presumably nonconscious) bias that serves to perpetuate and justify inequality. Because most of the relevant studies had been carried out in the 1970s and 1980s, Jost (1997) conducted a replication to see whether women in an explicitly feminist environment (Yale College in the 1990s) would internalize a depressed sense of entitlement. Results indicated that they did: Women "paid themselves" on average $18 \%$ less than men did for work that was indistinguishable with regard to quality. 
Work by Pelham and Hetts (2001) suggests that the depressed-entitlement effect is attributable to status inequality rather than to gender per se. They found that people who were employed in low-paying jobs, regardless of their gender, believed that their work on difficult (but not easy) tasks was worth less than did people who were employed in higher-paying jobs. This evidence suggests that people internalize the effects of inequality, adjusting their expectations to fit the status quo. More specifically:

Hypothesis 9. Members of disadvantaged groups (not just women) will exhibit a depressed sense of entitlement relative to members of advantaged groups, even in explicitly egalitarian environments.

Blanton, George, and Crocker (2001) drew on both cognitive dissonance and system justification theories to predict:

Hypothesis 10. Members of disadvantaged groups will be more likely to exhibit depressed entitlement (relative to members of advantaged groups) for past work that has already been completed than for future work that has not yet been completed.

This hypothesis was supported. Blanton et al. found that women felt they deserved less than men did in the "past work" condition but not in the "future work" condition, apparently because they felt a stronger need to justify past efforts than an indeterminate future. Research on the depressed-entitlement effect therefore demonstrates that a system justification perspective is useful for understanding phenomena in addition to stereotyping and outgroup favoritism, including judgments of one's own economic worth.

\section{Conflicts Among Ego, Group, and System Justification}

From a system justification perspective, members of disadvantaged groups are often faced with potential conflicts among ego, group, and system justification needs that are not experienced by members of advantaged groups (Jost et al., 2001). For example, women who are strongly committed to the belief that the status quo is legitimate are more likely to exhibit depressed-entitlement effects (Major, 1994) and to express sexism against women (Glick \& Fiske, 2001). To the extent that the strength of system justification motives surpasses that of ego and group justification motives, members of disadvantaged groups are not expected to engage in social change strategies to a substantial degree (see also Major et al., 2002; Schmader et al., 2001).

In addressing conflicts and trade-offs among group and system justification motives, Jost and Burgess (2000) argued that ingroup ratings made by low-status group members would reflect greater ambivalence than ratings made by highstatus group members. It was also predicted that for members of psychologically meaningful groups (for whom at least moderate levels of group justification 
motives would be present), ambivalence toward the ingroup would be (a) increased for members of low-status groups as system justification motives were increased, and (b) decreased for members of high-status groups as system justification motives were increased. Thus, the following hypotheses were assessed:

Hypothesis 11. Members of low-status groups will exhibit greater ambivalence toward their own group than will members of high-status groups.

Hypothesis 12. Members of low-status groups will exhibit increased ambivalence toward their own group as system justification is increased.

Hypothesis 13. Members of high-status groups will exhibit decreased ambivalence toward their own group as system justification is increased.

In an experimental study conducted with University of Maryland students, ambivalence toward the ingroup - operationalized in terms of various indirect measures of attitudinal conflict - was found to be higher for people who were led to believe that their group was relatively low in socioeconomic success than for people who were led to believe that their group was relatively high. As hypothesized, perceived legitimacy of the status differences increased ambivalence among low-status group members and decreased ambivalence among high-status group members. In a follow-up study, men and women read about a female plaintiff who posed a threat to the status quo by suing her university for gender discrimination. Jost and Burgess (2000) found that ambivalence toward the plaintiff correlated positively with just-world beliefs and SDO scores among women respondents, but it correlated negatively with SDO scores among men. This finding suggests that social dominance orientation is better conceptualized as a form of system justification, as argued also by Sidanius et al. (2001) and Overbeck et al. (2004), rather than as a form of group justification, as suggested by others (e.g., Altemeyer, 1998; Sidanius \& Pratto, 1993; Sniderman et al., 2000).

Jost and Thompson (2000) predicted that providing ideological support for existing systems of inequality would be associated with psychological advantages for European Americans and disadvantages for African Americans. Specifically, they hypothesized:

Hypothesis 14. System justification will be associated with (a) increased self-esteem for members of advantaged groups, and (b) decreased selfesteem for members of disadvantaged groups.

Hypothesis 15. System justification will be associated with (a) decreased depression for members of advantaged groups, and (b) increased depression for members of disadvantaged groups.

Hypothesis 16. System justification will be associated with (a) decreased neuroticism for members of advantaged groups, and (b) increased neuroticism for members of disadvantaged groups. 
In four studies, economic system justification and generalized opposition to equality were associated with decreased self-esteem and ingroup favoritism among African American respondents, as well as with increased neuroticism and depression. These same variables were associated with increased self-esteem and ingroup favoritism and decreased neuroticism and depression among European Americans (see also Chen \& Tyler, 2001). This evidence suggests that conflicts exist among ego, group, and system justification variables for members of lowstatus groups but not high-status groups, as first predicted by Jost and Banaji (1994).

\section{Enhanced System Justification Among the Disadvantaged}

In an editorial in the New York Times, Brooks (2003) asked, "Why don't people vote their own self-interest?" He went on to observe:

Every few years the Republicans propose a tax cut, and every few years the Democrats pull out their income distribution charts to show that much of the benefits of the Republican plan go to the richest 1\% of Americans or thereabouts. And yet every few years a Republican plan wends its way through the legislative process and, with some trims and amendments, passes... The Democrats couldn't even persuade people to oppose the repeal of the estate tax, which is explicitly for the mega-upper class. Al Gore, who ran a populist campaign, couldn't even win the votes of white males who didn't go to college, whose incomes have stagnated over the past decades and who were the explicit targets of his campaign. Why don't more Americans want to distribute more wealth down to people like themselves?

By postulating that people have psychological attachments to the status quo that supersede considerations of self-interest, system justification theory aspires to understand behavioral anomalies in social and political psychology. A system justification perspective helps to understand why people who are economically disadvantaged often oppose income redistribution (e.g., Fong, 2001; Gilens, 1999; Kluegel \& Smith, 1986), why women accept gender stereotypes and conventional definitions of sex roles (e.g., Glick \& Fiske, 2001; Jackman, 1994; Major, 1994), and why so many members of disadvantaged groups reject egalitarian alternatives to the status quo (e.g., Jost, Pelham, et al., 2003; Lane, 1959/2004; Lipset, 1981).

Other theories are ill-equipped to deal with these phenomena, mainly because they assume (either implicitly or explicitly) that social and political attitudes and behaviors follow from group identification, party membership, generalized ethnocentrism, dominance needs, and other individual or collective forms of symbolic or material self-interest. Sidanius et al. (2000), for example, wrote that "the SD approach asserts that one's commitment to equality is likely to be related to 
the social status of one's group, with members of dominant groups being more resistant to the redistribution of resources and less likely to endorse principles of equality" (p. 196). Social identity theorists agree with relatively few assumptions made by social dominance theorists, but they do concur that members of higherstatus groups hold more favorable attitudes than do members of low-status groups toward the preservation of the social order (e.g., see the exchange between Schmitt, Branscombe, \& Kappen, 2003, and Sidanius \& Pratto, 2003). Turner and Reynolds (2003) pointed out that social identity and social dominance perspectives lead to the common conclusion that "subordinate groups are more likely to reject the status quo than are dominant groups, consistent with the self-interest of both" (p. 201). By contrast, an emphasis on the system-justifying (rather than egojustifying or group-justifying) functions of attitudes, beliefs, and ideologies entails recognizing that preserving the status quo is a collaborative process in which, as Havel (1991) put it, "everyone . . . is both a victim and a supporter of the system" (p. 144).

The strongest, most paradoxical form of the system justification hypothesis, which draws also on the logic of cognitive dissonance theory, is that members of disadvantaged groups would be even more likely than members of advantaged groups to support the status quo, at least when personal and group interests are low in salience. Cognitive dissonance researchers are well known for having demonstrated that people who are most socially and physically deprived develop the strongest needs to justify their own suffering, in order to reduce dissonance (e.g., Wicklund \& Brehm, 1976). If there is a motive to justify the system in order to reduce ideological dissonance and defend against threats to the system's legitimacy, it follows that those who suffer the most from the system are also those who have the most to explain, justify, and rationalize (see also Lane, 1959/2004). Jost, Pelham et al. (2003) reported the results from five survey studies that provided the opportunity to investigate variations on the following hypothesis:

Hypothesis 17. When individual and group needs and interests are low in salience or strength, members of disadvantaged groups will provide stronger support for the social system and its authorities than will members of advantaged groups.

In one study, Jost, Pelham et al. (2003) found that low-income respondents and African Americans were more likely than high-income respondents and European Americans to support limitations on the rights of citizens and media representatives to criticize the government. In a second study, low-income Latinos were more likely to trust in government officials and to believe that "the government is run for the benefit of all" than were high-income Latinos, even after controlling for educational differences and excluding politically conservative Cuban respondents.

A third study addressed meritocratic ideology and found that (contrary to selfinterest) low-income respondents were more likely than high-income respondents 
to believe that large differences in pay are necessary to "get people to work hard" and "as an incentive for individual effort." Again, these effects retained significance after controlling for education. In the fourth study, African Americans living in the South (compared to African Americans living in the North) had lower income levels but endorsed meritocratic belief systems to a greater extent. In a fifth study, Jost, Pelham et al. (2003) found that low-income respondents and African Americans were more likely than high-income respondents and European Americans to believe that economic inequality is both legitimate and necessary.

Although we are certainly not claiming that members of disadvantaged groups will always (or even typically) exhibit stronger support for the system than will members of advantaged groups, our theoretical analysis is consistent with several other findings in the literature that have not been integrated previously. Specifically, members of groups that are low in socioeconomic success have been found to score higher than members of groups that are high in socioeconomic success on measures of right-wing authoritarianism (Altemeyer, 1981), political conservatism (Stacey \& Green, 1971), power distance (Hofstede, 1997), and the belief in a just world (Hunt, 2000). This evidence contradicts prevailing assumptions that social and political attitudes generally reflect self-interest and group membership and that dominant group members always take the lead in maintaining the social order. The fact that members of disadvantaged groups are-under some circumstances, at least-more likely than others to justify the system is consistent with the notion that they are motivated to reduce ideological dissonance in such a way that the status quo is preserved.

If the above line of reasoning is correct, another counterintuitive hypothesis concerning the reduction of ideological dissonance follows:

Hypothesis 18. System justification levels will be higher in societies in which social and economic inequality is more extreme rather than less extreme.

Although more research is needed to assess this hypothesis, Glick and Fiske (2001) found that men's and women's mean scores on both "hostile" and "benevolent" forms of sexism at the national level were negatively correlated with indices of gender development (women's education, longevity, and standard of living relative to that of men) and gender empowerment (women's representation in business and government) in 19 different countries. Glick and Fiske also found that "when men in a nation more strongly endorsed sexist ideologies, women followed suit, providing strong correlational evidence of system justification" (p. 114). Average within-country correlations between the sexism scores of men and women surpassed .80, indicating that consensual ideologies existed to rationalize gender inequality-especially in highly inegalitarian environments. 


\section{System-Justifying Effects of Exposure to Complementary Status and Gender Stereotypes}

Throughout this article, we have emphasized the valence of intergroup attitudes, especially the degree of ingroup versus outgroup favoritism. Recent studies suggest that system justification theory is also useful for understanding specific stereotype contents, regardless of valence. Kay and Jost (2003) hypothesized that exposure to compensatory representations of the poor as more honest and happy than the rich would lead to an increase in support for the status quo, insofar as such stereotypes maintain the belief that every group in society has its rewards and no group has a monopoly on everything that is valued:

Hypothesis 19. Exposure to complementary stereotype exemplars (in which members of high- and low-status groups are seen as having opposite, offsetting strengths and weaknesses) will increase system justification, in comparison to noncomplementary stereotype exemplars.

This hypothesis was corroborated in four experiments conducted by Kay and Jost (2003). Exposure to "poor but happy," "poor but honest," "rich but miserable," and "rich but dishonest" stereotype exemplars led people to score higher on a general, diffuse measure of system justification, compared to noncomplementary control conditions.

Building on Glick and Fiske's (2001) account of benevolent sexism as a system-justifying ideology, Jost and Kay (in press) argued that exposure to complementary gender stereotypes should also serve to increase women's support for the status quo. Specifically, they hypothesized:

Hypothesis 20. Exposure to benevolent and complementary gender stereotypes (in which women are seen as communal but not agentic) will increase system justification, especially among women, in comparison to neutral or noncomplementary stereotypes.

Studies by Jost and Kay (in press) showed that reminders of benevolent and complementary gender stereotypes increase both gender-specific and diffuse support for the system among women respondents, who might otherwise be less likely than men to view the status quo as fair, legitimate, and justified (e.g., Sidanius \& Pratto, 1999).

\section{Concluding Remarks}

In this overview of evidence pertaining to 20 hypotheses derived from system justification theory, we have highlighted research that is especially relevant to political psychology and to empirically verifiable differences between the system justification perspective and neighboring theories of social identification and 
social dominance. The evidence demonstrates that people are motivated not only to hold favorable attitudes toward themselves and toward members of their own groups (as other theories assume), but also to hold favorable attitudes toward the existing social system and the status quo. What is especially significant is that system justification motives are sometimes capable of overriding ego and group justification motives associated with the protection of individual and collective interests and esteem. In contrast to other theories, system justification theory unambiguously addresses the possibilities that (a) there is an ideological motive to justify the existing social order, (b) the motive is at least partially responsible for outgroup favoritism and the internalization of inferiority among members of disadvantaged groups, (c) it is observed most readily at an implicit, nonconscious level of awareness, and (d) paradoxically, it is sometimes strongest among those who are most disadvantaged by the social order.

In positing a general psychological tendency to justify and rationalize the status quo, we do not assume that everyone is equally motivated to engage in system justification. In this review, we have focused most extensively on political conservatism as an ideological variable that picks out an individual's propensity to resist change and rationalize inequality. Other individual-difference variables that are presumably related to general system justification tendencies include right-wing authoritarianism, belief in a just world, Protestant work ethic, power distance, and social dominance orientation, especially the "opposition to equality" factor (e.g., Jost \& Burgess, 2000; Jost \& Hunyady, 2002; Jost et al., 2003a; Kay \& Jost, 2003; Overbeck et al., 2004). In acknowledging the role of individual differences, therefore, our view is more consistent with social dominance theorists than with social identity theorists (see Huddy, 2004).

We do not believe, however, that the existing evidence is sufficient to warrant accepting the notion that hierarchy and inequality are genetically mandated at either the individual or species level, as argued by Sidanius and Pratto (1993, 1999). On this issue, we are closer to the social constructionist position taken by social identity theorists (e.g., Berger \& Luckmann, 1966; Jost \& Kruglanski, 2002; Reicher, 2004; Tajfel, 1981). What seems less speculative to us (but speculative nonetheless, given the dearth of direct evidence concerning the circumstances of our evolutionary history) is the possibility that human beings have developed generally adaptive capacities to accommodate, internalize, and even rationalize key features of their socially constructed environments, especially those features that are difficult or impossible to change (e.g., Gilbert, Pinel, Wilson, Blumberg, \& Wheatley, 1998; Kay et al., 2002; McGuire \& McGuire, 1991; Wilson, Wheatley, Kurtz, Dunn, \& Gilbert, 2004). The social and political implications of this simple assumption are vast indeed, and they may help us to understand why, for better and for worse, the status quo exerts such a powerful hold on us, whether or not it serves our interests, and whether or not we are aware of its influence. 


\section{ACKNOWLEDGMENTS}

This work was completed while the first author was a fellow at the Radcliffe Institute for Advanced Study at Harvard University. We are particularly grateful to the Institute for sponsoring a year-long reunion for the first two authors. We also thank Jim Sidanius for taking the initiative to organize this forum, and Dolly Chugh, Laura Gibson, Orsolya Hunyady, Dale Miller, and Erik Thompson for providing comments on earlier versions of the article. Correspondence concerning this article should be sent to John T. Jost, Department of Psychology, New York University, 6 Washington Place, 5th Floor, New York, NY 10003. E-mail: john.jost@nyu.edu

\section{REFERENCES}

Abrams, D., \& Hogg, M. A. (Eds.) (1990). Social identity theory: Constructive and critical advances. New York: Springer-Verlag.

Adorno, T. W., Frenkel-Brunswik, E., Levinson, D. J., \& Sanford, R. N. (1950). The authoritarian personality. New York: Harper.

Allen, V. L., \& Wilder, D. A. (1975). Categorization, belief similarity, and group discrimination. Journal of Personality and Social Psychology, 32, 971-977.

Allport, G. W. (1954). The nature of prejudice. Cambridge, MA: Addison-Wesley.

Altemeyer, R. A. (1981). Right-wing authoritarianism. Winnipeg: University of Manitoba Press.

Altemeyer, R. A. (1998). The other "authoritarian personality." Advances in Experimental Social Psychology, 30, 47-92.

Ashburn-Nardo, L., Knowles, M. L., \& Monteith, M. J. (2003). Black Americans' implicit racial associations and their implications for intergroup judgment. Social Cognition, 21, 61-87.

Banaji, M. R., Greenwald, A. G., \& Rosier, M. (1997). Implicit esteem: When collectives shape individuals. Paper presented at the Self \& Identity Preconference, Toronto.

Berger, P. L., \& Luckmann, T. (1966). The social construction of reality: A treatise in the sociology of knowledge. Garden City, NY: Anchor.

Blanton, H., George, G., \& Crocker, J. (2001). Contexts of system justification and system evaluation: Exploring the social comparison strategies of the (not yet) contented female worker. Group Processes and Intergroup Relations, 4, 127-138.

Bobo, L. (1988). Group conflict, prejudice and the paradox of contemporary racial attitudes. In P. A. Katz \& D. A. Taylor (Eds.), Eliminating racism: Profiles in controversy (pp. 85-116). New York: Plenum.

Brewer, M. B. (1979). Ingroup bias in the minimal intergroup situation: A cognitive-motivational analysis. Psychological Bulletin, 86, 307-324.

Brewer, M. B., \& Campbell, D. T. (1976). Ethnocentrism and intergroup attitudes. New York: Wiley.

Brewer, M. B., \& Miller, N. (1996). Intergroup relations. Buckingham, UK: Open University Press.

Brooks, D. (2003, 12 January). The triumph of hope over self-interest. New York Times, Section 4, p. 15.

Brown, R. (1988). Group processes: Dynamics within and between groups (1st ed.). Oxford: Blackwell.

Brown, R. (2000a). Social identity theory: Past achievements, current problems and future challenges. European Journal of Social Psychology, 30, 745-778. 
Brown, R. (2000b). Group processes: Dynamics within and between groups (2nd ed.). Oxford: Blackwell.

Centers, R. (1949). The psychology of social classes. Princeton, NJ: Princeton University Press.

Chanley, V. A. (2002). Trust in government in the aftermath of 9/11: Determinants and consequences. Political Psychology, 23, 469-483.

Chen, E. S., \& Tyler, T. R. (2001). Cloaking power: Legitimizing myths and the psychology of the advantaged. In A. Y. Lee-Chai \& J. Bargh (Eds.), The use and abuse of power: Multiple perspectives on the causes of corruption (pp. 241-261). Philadelphia: Psychology Press.

Cialdini, R. B., Borden, R. J., Thorne, A., Walker, M. R., Freeman, S., \& Sloan, L. R. (1976). Basking in reflected glory: Three (football) field studies. Journal of Personality and Social Psychology, $39,406-415$.

Correll, J., Park, B., Judd, C. M., \& Wittenbrink, B. (2002). The police officer's dilemma: Using ethnicity to disambiguate potentially threatening individuals. Journal of Personality and Social Psychology, 83, 1314-1329.

Deutsch, M. (1985). Distributive justice. New Haven, CT: Yale University Press.

Dovidio, J. F., \& Gaertner, S. L. (Eds.) (1986). Prejudice, discrimination, and racism. Orlando, FL: Academic Press.

Downs, A. (1957). An economic theory of democracy. New York: Harper \& Row.

Ellemers, N., Wilke, H., \& van Knippenberg, A. (1993). Effects of the legitimacy of low group or individual status on individual and collective status-enhancement strategies. Journal of Personality and Social Psychology, 64, 766-778.

Fiske, S. T. (1993). Controlling other people. American Psychologist, 48, 621-628.

Fong, C. (2001). Social preferences, self-interest, and the demand for redistribution. Journal of Public Economics, 82, 225-246.

Gilbert, D. T., Pinel, E. C., Wilson, T. D., Blumberg, S. J., \& Wheatley, T. (1998). Immune neglect: A source of durability bias in affective forecasting. Journal of Personality and Social Psychology, 75, 617-638.

Gilens, M. (1999). Why Americans hate welfare: Race, media, and the politics of antipoverty policy. Chicago: University of Chicago Press.

Glick, P., \& Fiske, S. T. (2001). An ambivalent alliance: Hostile and benevolent sexism as complementary justifications for gender inequality. American Psychologist, 56, 109-118.

Goodwin, S., \& Devos, T. (2002). American identity under siege: National and racial identities in the wake of the September 11th attack. Paper presented at the annual meeting of the Society for Experimental Social Psychology, Columbus, OH.

Greenwald, A. G. (1980). The totalitarian ego: Fabrication and revision of personal history. American Psychologist, 35, 603-618.

Greenwald, A. G., \& Banaji, M. R. (1995). Implicit social cognition: Attitudes, self-esteem, and stereotypes. Psychological Review, 102, 4-27.

Greenwald, A. G., McGhee, D. E., \& Schwartz, J. L. K. (1998). Measuring individual differences in implicit cognition: The Implicit Association Test. Journal of Personality and Social Psychology, 74, 1464-1480.

Greenwald, A. G., Nosek, B. A., \& Banaji, M. R. (2003). Understanding and using the Implicit Association Test: I. An improved scoring algorithm. Journal of Personality and Social Psychology, $85,197-216$.

Gurr, T. R. (1970). Why men rebel. Princeton, NJ: Princeton University Press.

Haines, E. L., \& Jost, J. T. (2000). Placating the powerless: Effects of legitimate and illegitimate explanation on affect, memory, and stereotyping. Social Justice Research, 13, 219-236.

Havel, V. (1991). The power of the powerless. In Open letters: Selected writings 1965-1990 (pp. 125-214). London: Faber \& Faber. 
Hewstone, M., \& Jaspars, J. (1984). Social dimensions of attribution. In H. Tajfel (Ed.), The social dimension: European developments in social psychology (vol. 2, pp. 379-404). Cambridge: Cambridge University Press.

Hewstone, M., \& Ward, C. (1985). Ethnocentrism and causal attribution in southeast Asia. Journal of Personality and Social Psychology, 48, 614-623.

Hill, M. E. (2002). Skin color and the perception of attractiveness among African Americans: Does gender make a difference? Social Psychology Quarterly, 65, 77-91.

Hinkle, S., \& Brown, R. (1990). Intergroup comparisons and social identity: Some links and lacunae. In D. Abrams \& M. A. Hogg (Eds.), Social identity theory: Constructive and critical advances (pp. 48-70). New York: Springer-Verlag.

Hirschman, A. O. (1970). Exit, voice, and loyalty: Responses to decline in firms, organizations, and states. Cambridge, MA: Harvard University Press.

Hofstede, G. (1997). Cultures and organizations. New York: McGraw-Hill.

Hornsey, M. J., Spears, R., Cremers, I., \& Hogg, M. A. (2003). Relations between high and low power groups: The importance of legitimacy. Personality and Social Psychology Bulletin, 29, $216-227$.

Huddy, L. (2004). Contrasting theoretical approaches to intergroup relations. Political Psychology, 25, 947-967.

Huddy, L., Feldman, S., Capelos, T., \& Provost, C. (2002). The consequences of terrorism: Disentangling the effects of personal and national threat. Political Psychology, 23, 485-509.

Hunt, M. O. (2000). Status, religion, and the "belief in a just world": Comparing African Americans, Latinos, and whites. Social Science Quarterly, 81, 325-343.

Jackman, M. R. (1994). The velvet glove: Paternalism and conflict in gender, class, and race relations. Berkeley, CA: University of California Press.

Jackman, M. R., \& Senter, M. S. (1983). Different, therefore unequal: Beliefs about trait differences between groups of unequal status. Research in Social Stratification and Mobility, 2, 309-335.

Jost, J. T. (1997). An experimental replication of the depressed entitlement effect among women. Psychology of Women Quarterly, 21, 387-393.

Jost, J. T. (2001). Outgroup favoritism and the theory of system justification: An experimental paradigm for investigating the effects of socio-economic success on stereotype content. In G. Moskowitz (Ed.), Cognitive social psychology: The Princeton symposium on the legacy and future of social cognition (pp. 89-102). Mahwah, NJ: Erlbaum.

Jost, J. T., \& Banaji, M. R. (1994). The role of stereotyping in system-justification and the production of false consciousness. British Journal of Social Psychology, 33, 1-27.

Jost, J. T., \& Burgess, D. (2000). Attitudinal ambivalence and the conflict between group and system justification motives in low status groups. Personality and Social Psychology Bulletin, 26, 293-305.

Jost, J. T., Burgess, D., \& Mosso, C. (2001). Conflicts of legitimation among self, group, and system: The integrative potential of system justification theory. In J. T. Jost \& B. Major (Eds.), The psychology of legitimacy: Emerging perspectives on ideology, justice, and intergroup relations (pp. 363-388). New York: Cambridge University Press.

Jost, J. T., Glaser, J., Kruglanski, A. W., \& Sulloway, F. (2003a). Political conservatism as motivated social cognition. Psychological Bulletin, 129, 339-375.

Jost, J. T., Glaser, J., Kruglanski, A. W., \& Sulloway, F. (2003b). Exceptions that prove the rule: Using a theory of motivated social cognition to account for ideological incongruities and political anomalies. Psychological Bulletin, 129, 383-393.

Jost, J. T., \& Hunyady, O. (2002). The psychology of system justification and the palliative function of ideology. European Review of Social Psychology, 13, 111-153.

Jost, J. T., \& Kay, A. C. (in press). Exposure to benevolent sexism and complementary gender stereotypes: Consequences for specific and diffuse forms of system justification. Journal of Personality and Social Psychology, forthcoming. 
Jost, J. T., \& Kruglanski, A. W. (2002). The estrangement of social constructionism and experimental social psychology: History of the rift and prospects for reconciliation. Personality and Social Psychology Review, 6, 168-187.

Jost, J. T., Pelham, B. W., \& Carvallo, M. (2002). Non-conscious forms of system justification: Cognitive, affective, and behavioral preferences for higher status groups. Journal of Experimental Social Psychology, 38, 586-602.

Jost, J. T., Pelham, B. W., Sheldon, O., \& Sullivan, B. N. (2003). Social inequality and the reduction of ideological dissonance on behalf of the system: Evidence of enhanced system justification among the disadvantaged. European Journal of Social Psychology, 33, 13-36.

Jost, J. T., \& Thompson, E. P. (2000). Group-based dominance and opposition to equality as independent predictors of self-esteem, ethnocentrism, and social policy attitudes among African Americans and European Americans. Journal of Experimental Social Psychology, 36, 209-232.

Kappen, D., \& Branscombe, N. R. (2001). The effects of reasons given for ineligibility on perceived gender discrimination and feelings of injustice. British Journal of Social Psychology, 40, 295-313.

Kay, A., Jimenez, M. C., \& Jost, J. T. (2002). Sour grapes, sweet lemons, and the anticipatory rationalization of the status quo. Personality and Social Psychology Bulletin, 28, 1300-1312.

Kay, A. C., \& Jost, J. T. (2003). Complementary justice: Effects of "poor but happy" and "poor but honest" stereotype exemplars on system justification and implicit activation of the justice motive. Journal of Personality and Social Psychology, 85, 823-837.

Kilianski, S. E., \& Rudman, L. A. (1998). Wanting it both ways: Do women approve of benevolent sexism? Sex Roles, 39, 333-352.

Kluegel, J. R., \& Smith, E. R. (1986). Beliefs without inequality: Americans' view of what is and what ought to be. Hawthorne, NJ: Aldine de Gruyter.

Lane, K. A., Mitchell, J. P., \& Banaji, M. R. (2003). Implicit group evaluation: Ingroup preference, outgroup preference, and the rapid creation of implicit attitudes. Unpublished manuscript, Harvard University.

Lane, R. E. (2004). The fear of equality. In J. T. Jost \& J. Sidanius (Eds.), Political psychology: Key readings. New York: Psychology Press/Taylor \& Francis. (Original work published 1959)

Leach, C. W., Spears, R., Branscombe, N. R., \& Doosje, B. (2003). Malicious pleasure: Schadenfreude at the suffering of another group. Journal of Personality and Social Psychology, 84, 932-943.

Levin, S., Sidanius, J., Rabinowitz, J. L., \& Federico, C. (1998). Ethnic identity, legitimizing ideologies, and social status: A matter of ideological asymmetry. Political Psychology, 19, 373-404.

Levy, B., \& Banaji, M. R. (2002). Implicit ageism. In T. Nelson (Ed.), Ageism: Stereotyping and prejudice against older persons (pp. 49-75). Cambridge, MA: MIT Press.

Lipset, S. M. (1981). Working-class authoritarianism. In Political man: The social bases of politics (expanded ed., pp. 87-126). Baltimore: Johns Hopkins University Press.

Livingston, R. W. (2002). The role of perceived negativity in the moderation of African Americans' implicit and explicit racial attitudes. Journal of Experimental Social Psychology, 38, 405-413.

Major, B. (1994). From social inequality to personal entitlement: The role of social comparisons, legitimacy appraisals, and group memberships. Advances in Experimental Social Psychology, 26, 293-355

Major, B., Gramzow, R. H., McCoy, S. K., Levin, S., Schmader, T., \& Sidanius, J. (2002). Perceiving personal discrimination: The role of group status and legitimizing ideology. Journal of Personality and Social Psychology, 82, 269-282.

McGuire, W. J. (1997). Creative hypothesis generating in psychology: Some useful heuristics. Anпиal Review of Psychology, 48, 1-30.

McGuire, W. J., \& McGuire, C. V. (1991). The content, structure, and operation of thought systems. Advances in Social Cognition, 4, 1-78.

Miller, D. T. (1999). The norm of self-interest. American Psychologist, 54, 1-8. 
Miller, D. T., \& Ratner, R. K. (1998). The disparity between the actual and assumed power of selfinterest. Journal of Personality and Social Psychology, 74, 53-62.

Moore, D. W. (2001, 9 October). Bush support rides wave of anti-terrorism: Ratings on job performance, personal characteristics soar (Poll analyses, Gallup Organization). Retrieved 12 July 2004 from http://www.gallup.com/content/login.aspx?ci=4975.

Mullen, B., Brown, R., \& Smith, C. (1992). Ingroup bias as a function of salience, relevance, and status: An integration. European Journal of Social Psychology, 22, 103-122.

Newman, K. (2002). No shame: The view from the left bank. American Journal of Sociology, 107, $1577-1599$.

Nosek, B. A., Banaji, M. R., \& Greenwald, A. G. (2002a). Harvesting implicit group attitudes and beliefs from a demonstration website. Group Dynamics, 6, 101-115.

Nosek, B. A., Banaji, M. R., \& Greenwald, A. G. (2002b). eResearch: Ethics, security, design, and control in psychological research on the Internet. Journal of Social Issues, 58, 161-176.

Oakes, P. J., Haslam, A., \& Turner, J. C. (1994). Stereotyping and social reality. Cambridge, MA: Blackwell.

Olson, M. (1971). The logic of collective action. Cambridge, MA: Harvard University Press.

Overbeck, J., Jost, J. T., Mosso, C., \& Flizik, A. (2004). Resistant vs. acquiescent responses to ingroup inferiority as a function of social dominance orientation in the USA and Italy. Group Processes and Intergroup Relations, 7, 35-54.

Pelham, B. W., \& Hetts, J. J. (2001). Underworked and overpaid: Elevated entitlement in men's selfpay. Journal of Experimental Social Psychology, 37, 93-103.

Pettigrew, T. (1982). Prejudice. Cambridge, MA: Harvard University Press.

Pratto, F., Sidanius, J., Stallworth, L. M., \& Malle, B. F. (1994). Social dominance orientation: A personality variable predicting social and political attitudes. Journal of Personality and Social Psychology, 67, 741-763.

Pyszczynski, T., Solomon, S., \& Greenberg, J. (2003). In the wake of 9/11: The psychology of terror. Washington, DC: APA Press.

Ratner, R. K., \& Miller, D. T. (2001). The norm of self-interest and its effects on social action. Journal of Personality and Social Psychology, 81, 5-16.

Reicher, S. (2004). The context of social identity: Domination, resistance, and change. Political Psychology, 25, 921-945.

Reicher, S., \& Levine, M. (1994). Deindividuation, power relations between groups and the expression of social identity: The effects of visibility to the out-group. British Journal of Social Psychology, 33, 145-163.

Rubin, M., \& Hewstone, M. (2004). Commentary on Reicher, Jost et al., and Sidanius et al. Political Psychology, 25, 823-844.

Rudman, L. A., Feinberg, J., \& Fairchild, K. (2002). Minority members' implicit attitudes: Automatic ingroup bias as a function of group status. Social Cognition, 20, 294-320.

Saad, L. (2003, 25 March). Iraq war triggers major rally effect: Falls just short of 1991 surge in public attitudes (Poll analyses, Gallup Organization). Retrieved 12 July 2004 from http://www.gallup.com/content/login.aspx?ci=8074.

Scheepers, D., Branscombe, N. R., Spears, R., \& Doosje, B. (2002). The emergence and effects of deviants in low and high status groups. Journal of Experimental Social Psychology, 38, 611-617.

Schmader, T., Major, B., Eccleston, C. P., \& McCoy, S. K. (2001). Devaluing domains in response to threatening intergroup comparisons: Perceived legitimacy and the status value asymmetry. Journal of Personality and Social Psychology, 80, 782-796.

Schmitt, M. T., Branscombe, N. R., \& Kappen, D. M. (2003). Attitudes toward group-based inequality: Social dominance or social identity? British Journal of Social Psychology, 42, 161-186.

Scott, J. (1990). Domination and the arts of resistance. New Haven, CT: Yale University Press. 
Sears, D., \& Funk, C. (1991). The role of self-interest in social and political attitudes. Advances in Experimental Social Psychology, 24, 1-92.

Sedikides, C., Schopler, J., \& Insko, C. A. (Eds.) (1998). Intergroup cognition and intergroup behavior. Mahwah, NJ: Erlbaum.

Sherif, M. (1967). Group conflict and co-operation. London: Routledge \& Kegan Paul.

Sidanius, J. (1993). The psychology of group conflict and the dynamics of oppression: A social dominance perspective. In S. Iyengar \& W. J. McGuire (Eds.), Explorations in political psychology (pp. 183-219). Durham, NC: Duke University Press

Sidanius, J., \& Ekehammar, B. (1979). Political socialization: A multivariate analysis of Swedish political attitude and preference data. European Journal of Social Psychology, 9, 265-279.

Sidanius, J., Levin, S., Federico, C., \& Pratto, F. (2001). Legitimizing ideologies: The social dominance approach. In J. T. Jost \& B. Major (Eds.), The psychology of legitimacy: Emerging perspectives on ideology, justice, and intergroup relations (pp. 307-331). New York: Cambridge University Press.

Sidanius, J., \& Pratto, F. (1993). The inevitability of oppression and the dynamics of social dominance. In P. Sniderman, P. E. Tetlock, \& E. G. Carmines (Eds.), Prejudice, politics, and the American dilemma (pp. 173-211). Stanford, CA: Stanford University Press.

Sidanius, J., \& Pratto, F. (1999). Social dominance: An intergroup theory of social hierarchy and oppression. New York: Cambridge University Press.

Sidanius, J., \& Pratto, F. (2003). Social dominance theory and the dynamics of inequality: A reply to Schmitt, Branscombe, \& Kappen and Wilson \& Liu. British Journal of Social Psychology, 42, 207-213.

Sidanius, J., Singh, P., Hetts, J. J., \& Federico, C. (2000). It's not affirmative action, it's the blacks: The continuing relevance of race in American politics. In D. O. Sears, J. Sidanius, \& L. Bobo (Eds.), Racialized politics: The debate about racism in America (pp. 191-235). Chicago: University of Chicago Press.

Smith, E. R., \& Mackie, D. M. (2002). Commentary. In D. M. Mackie \& E. R. Smith (Eds.), From prejudice to intergroup emotions: Differentiated reactions to social groups (pp. 285-299). New York: Psychology Press.

Sniderman, P., Crosby, G., \& Howell, W. (2000). The politics of race. In D. O. Sears, J. Sidanius, \& L. Bobo (Eds.), Racialized politics: The debate about racism in America (pp. 236-279). Chicago: University of Chicago Press.

Sniderman, P., \& Piazza, T. (1993). The scar of race. Cambridge, MA: Harvard University Press.

Spears, R., Jetten, J., \& Doosje, B. (2001). The (il)legitimacy of ingroup bias: From social reality to social resistance. In J. T. Jost \& B. Major (Eds.), The psychology of legitimacy: Emerging perspectives on ideology, justice, and intergroup relations (pp. 332-362). New York: Cambridge University Press.

Spears, R., Oakes, P., Ellemers, N., \& Haslam, S. A. (Eds.) (1997). The social psychology of stereotyping and group life. Oxford: Blackwell.

Spicer, C. V., \& Monteith, M. J. (2001). Implicit outgroup favoritism among blacks and vulnerability to stereotype threat. Unpublished manuscript, University of Kentucky.

Stacey, B. G., \& Green, R. T. (1971). Working-class conservatism: A review and an empirical study. British Journal of Social and Clinical Psychology, 10, 10-26.

Stangor, C., \& Jost, J. T. (1997). Individual, group, and system levels of analysis and their relevance for stereotyping and intergroup relations. In R. Spears, P. Oakes, N. Ellemers, \& S. A. Haslam (Eds.), The social psychology of stereotyping and group life (pp. 336-358). Oxford: Blackwell.

Stephan, W. G., \& Stephan, W. S. (1996). Intergroup relations. Boulder, CO: Westview.

Sumner, W. G. (1906). Folkways. New York: Ginn.

Tajfel, H. (1975). The exit of social mobility and the voice of social change: Notes on the social psychology of intergroup relations. Social Science Information, 14, 101-118. 
Tajfel, H. (1981). Human groups and social categories. Cambridge: Cambridge University Press.

Tajfel, H. (Ed.) (1984). The social dimension: European developments in social psychology (vols. 1-2). Cambridge: Cambridge University Press.

Tajfel, H., \& Turner, J. C. (1986). The social identity theory of intergroup behavior. In S. Worchel \& W. G. Austin (Eds.), The psychology of intergroup relations (pp. 7-24). Chicago: Nelson-Hall.

Taylor, D. M., \& Moghaddam, F. M. (1994). Theories of intergroup relations: International social psychological perspectives (2nd ed.). New York: Praeger.

Tsui, A. S., Egan, T. D., \& O'Reilly, C. A. (1992). Being different: Relational demography and organizational attachment. Administrative Science Quarterly, 37, 549-579.

Turner, J. C., \& Brown, R. (1978). Social status, cognitive alternatives, and intergroup relations. In H. Tajfel (Ed.), Differentiation between social groups: Studies in the social psychology of intergroup relations (pp. 201-234). London: Academic Press.

Turner, J. C., \& Giles, H. (Eds.) (1981). Intergroup behavior. Chicago: University of Chicago Press.

Turner, J. C., Hogg, M. A., Oakes, P. J., Reicher, S. D., \& Wetherell, M. S. (1987). Rediscovering the social group: A self-categorization theory. Oxford: Blackwell.

Turner, J. C., \& Reynolds, K. (2003). Why social dominance theory has been falsified. British Journal of Social Psychology, 42, 199-206.

Uhlmann, E., Dasgupta, N., Elgueta, A., Greenwald, A. G., \& Swanson, J. (2002). Subgroup prejudice based on skin color among Hispanics in the United States and Latin America. Social Cognition, 20, 198-225.

Walker, I., \& Smith, H. J. (Eds.) (2002). Relative deprivation: Specification, development, and integration. Cambridge: Cambridge University Press.

Wicklund, R. A., \& Brehm, J. W. (1976). Perspectives on cognitive dissonance. Hillsdale, NJ: Erlbaum.

Wilson, G. D. (Ed.) (1973). The psychology of conservatism. London: Academic Press.

Wilson, T. D., Wheatley, T., Kurtz, J., Dunn, E., \& Gilbert, D. T. (2004). When to fire: Anticipatory versus post-event reconstrual of uncontrollable events. Personality and Social Psychology Bulletin, 30, 340-351.

Wright, S. C., Taylor, D. M., \& Moghaddam, F. M. (1990). Responding to membership in a disadvantaged group: From acceptance to collective protest. Journal of Personality and Social Psychology, 58, 994-1003.

Zinn, H. (1968). Disobedience and democracy: Nine fallacies on law and order. New York: Vintage. 